\title{
Cancer: A
}

\section{Comprehensive Review}

Editors

Gülçin GACAR Elif D. ÜNAL

Sema YUSUFOĞLU 


\title{
(C) Copyright 2020
}

Printing, broadcasting and sales rights of this book are reserved to Akademisyen Publishing House Inc. All or parts of this book may not be reproduced, printed or distributed by any means mechanical, electronic, photocopying, magnetic paper and/or other methods without prior written permission of the publisher. Tables, figures and graphics cannot be used for commercial purposes without permission. This book is sold with banderol of Republic of Turkey Ministry of Culture.

ISBN

978-625-7795-15-9

Book Title

Cancer: A Comprehensive Review

Editors

Gülçin GACAR

ORCID iD: 0000-0003-2960-6826

Elif D. ÜNAL

ORCID iD: 0000-0001-6725-3959

Sema YUSUFOĞLU

ORCID iD: 0000-0003-3117-388X

\section{Publishing Coordinator}

Yasin Dilmen

Page and Cover Design

Typesetting and Cover Design by Akademisyen

Publisher Certificate Number

25465

\section{Printing and Binding}

Vadi Matbaacilik

\author{
Bisac Code \\ MED058160
}

\section{GENERAL DISTRIBUTION Akademisyen Kitabevi A.Ş.}

Halk Sokak 5 / A

Yenişehir / Ankara

Tel: o312 4311633

siparis@akademisyen.com 


\section{PREFACE}

According to the oldest known records, cancer, which has more than 100 species starting from Egypt in 3000 BC, is among the reasons for the main lines of the studies carried out by many researchers; increases in the number of incidence and deaths, complex structure, advantages and disadvantages, and at the same time, these options are open to developments with the help of biotechnology.

So what is cancer? It occurs when cells in any part of the body begin to divide, multiply and accumulate in an uncontrolled way due to genetic and environmental factors, and at the same time contain the potential to spread to distant tissues and organs and prevent these tissues and organs from performing their functions by suppressing their functions; it is a disease not only biological but also psychological, social and with economic dimensions. The International Agency for Research on Cancer (IARC) states that by 2030 , cancer may be placed first in the list of causes of death.

At this point, increasing the success rates of cancers determined by various standards is related to remembering that it is an individual illness. Because despite all approaches in cancer treatment, each individual has a different DNA structure, division, and control of cells is under the control of genes, and cancer cells are competent cells with their metabolism. Therefore, it is not surprising that individuals respond differently to treatments.

Approaches to cancer, standardized treatments, studies, and articles on cancer provide an endless resource on cancer definition, standards, occurrence and development, mechanisms, new immunological and biological treatment methods including experimental treatments, and many other related topics. This book aims to bring together the long and detailed researches required to reach accurate and straightforward information in one place, 
to create a bridge between complex information, to provide a detailed perspective on each stage of cancer and cancer stem cells, To give information by comparing experimental treatment methods. 


\section{CONTENTS}

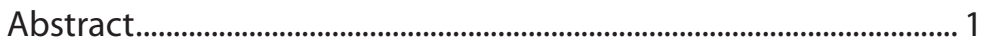

Definition of Cancer .................................................................................... 1

The Placement of Cancer in Causes of Death.......................................... 2

Deaths by Type of Cancer ....................................................................... 4

History of Cancer Stem Cells ........................................................................ 7

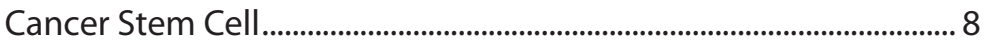

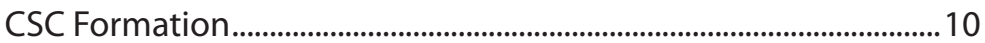

How Do Cancer Stem Cells Occur?.......................................................... 11

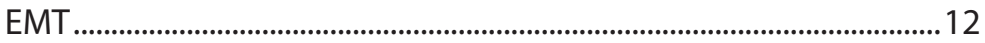

Matrix Metalloproteinases ................................................................15

Metalloproteinase tissue inhibitors (TIMP) ......................................... 19

Microenvironment ......................................................................................21

1. Inflammatory Environment..........................................................23

2. Hypoxic Environment (Lack of Oxygen) .........................................26

3. Acidosis (Acidic Environment)............................................................27

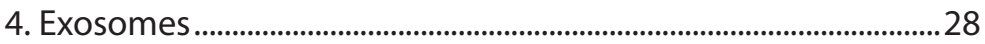

Metastasis, Invasion and Angiogenesis..........................................29

Angiogenesis ................................................................................................... 31

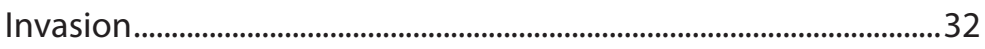

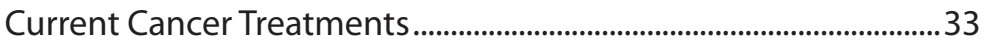

Radiotherapy ............................................................................................ 35

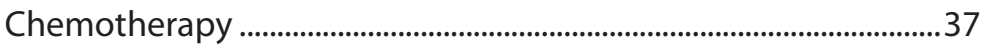

Stem Cell Therapy..................................................................................4

Hormonal Treatments................................................................................44

Surgical Methods...................................................................................4

Biological Treatments: Immunotherapy, Cancer

Vaccines, Cancer Growth Inhibitors, Gene Therapy...................47

Adoptive Immunotherapy .......................................................................48

Immune System Supportive Treatments ............................................49 
vi Contents

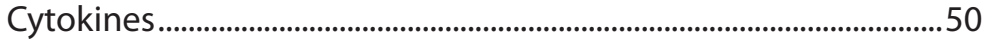

Antibody Treatments ..........................................................................52

Monoclonal Antibodies (mAb) and Their

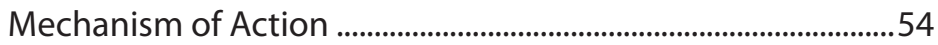

Cetuximab and Panitumumab ..........................................................56

Trastuzumab (Herceptin) .......................................................................57

Rituximab and Similar.........................................................................5

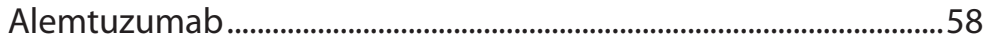

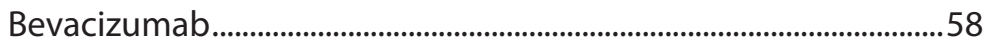

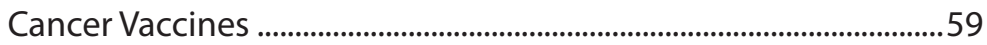

Cancer Growth Inhibitors ..........................................................................61

Gene Therapy..................................................................................................62

Other Treatment Methods ...............................................................64

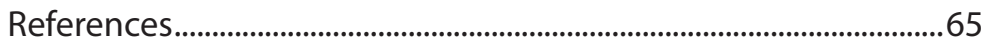




\section{References}

1. Acloque H. et al . (2009) Epithelial-mesenchymal transitions: The importance of changing cell state in development and disease. J Clin Invest 119: 1438-49. DOI: 10.1172/JCI38019actions and therapeutic opportunities. J Cell Sci;115:3719-3727.

2. Adams JM, Strasser A. (2008) Is tumor growth sustained by rare cancer stem cells or dominant clones? Cancer Res. 68: 4018-21. DOI: 10.1158/00085472.CAN-07-6334.

3. Adams, G. P. (2005), Monoclonal antibody therapy of cancer. Nature Biotechnology,1147-1157. DOI: 10.1038/nbt1137

4. Agorastos, T. et al. (2015) Primary Screening for Cervical Cancer Based on High-Risk Human Papillomavirus (HPV) Detection and HPV 16 and HPV 18 Genotyping, in Comparison to Cytology. Plos One 10: e0119755. DOI: 10.1371/journal.pone.0119755.

5. Aguilar-Gallardo C, Simon C. (2013) Cells, stem cells, and cancer stem cells. Semin Reprod Med.; 31: 5-13. DOI: 10.1055/s-0032-1331792

6. Aguilar-Gallardo, C. \& Simón, C. (2013) Cells, Stem Cells, and Cancer Stem Cells. Seminars in Reproductive Medicine ; 31: 005-013. DOI: 10.1055/s0032-1331792

7. Aifa S, Rebai A. (2008) ErbB antagonists patenting: "playing chess with cancer". Recent Pat Biotechnol; 2: 181- 187.

8. Alduaij, W., \& Illidge, T. M. (2011) The future of anti-CD20 monoclonal antibodies: are we making progress? Blood, 117(11), 2993-3001. DOI: 10.1182/blood-2010-07-298356

9. Alečković, M. \& Kang, Y. (2015) Welcoming Treat: Astrocyte-Derived Exosomes Induce PTEN Suppression to Foster Brain Metastasis. Cancer Cell 28: 554-556. DOI. org/10.1016/j.ccell.2015.10.010.

10. Al-Hajj M, et al. (2003) Prospective identification of tumorigenic breast cancer cells. Proc Natl Acad Sci USA. 100:3983-3988. DOI:10.1073/ pnas. 0530291100

11. Ali, O. A., et al., (2009) In Situ Regulation of DC Subsets and T Cells Mediates Tumor Regression in Mice. Science Translational Medicine 1: 8ra19. DOI: $10.1126 /$ scitranslmed.3000359

12. Ali, S. et al. (2016) Current Management Strategies in Breast Cancer by Targeting Key Altered Molecular Players. Frontiers in Oncology 6: 45. DOI: 10.3389 /fonc.2016.00045

13. Allan AL, et al., (2007) Tumor dormancy and cancer stem cells: implications for the biology and treatment of breast cancer metastasis. Breast Dis. 26: 87-98. DOI: 10.3233/BD-2007-26108

14. Allan AL, Vantyghem SA, Tuck AB, Chambers AF. (2007) Tumor dormancy and cancer stem cells: implications for the biology and treatment of breast 
cancer metastasis. Breast Dis. 2007; 26: 87-98. DOI: 10.3233/BD-200726108

15. Almendro, V., Marusyk, A. \& Polyak, K. (2013) Cellular Heterogeneity and Molecular Evolution in Cancer. Annual Review of Pathology: Mechanisms of Disease 8: 277-302. DOI: 10.1146/annurev-pathol-020712-163923.

16. Al-Zoughbi W, et al. (2014) Tumor macroenvironment and metabolism. Semin Oncol. 41: 281-95. DOI: 10.1053/j.seminoncol.2014.02.005

17. Anderson, W. F., Blaese, R. M. \& Culver, K. (1990) The ADA human gene therapy clinical protocol: Points to Consider response with clinical protocol, Human gene therapy 1: 331-362. DOI: 10.1089/hum.1990.1.3-331 ANKEM Derg 19(Ek 2):123-125.

18. Aroeira, L. S. et al. (2007) Epithelial to Mesenchymal Transition and Peritoneal Membrane Failure in Peritoneal Dialysis Patients: Pathologic Significance and Potential Therapeutic Interventions. Journal of the American Society of Nephrology 18: 2004-2013. DOI:10.1681/ASN.2006111292

19. Aslan Ö., et al., (2006) Kemoterapi Alan Kanser Hastalarına Verilen Eğitimin Kemoterapi Semptomlarına Etkisi C.Ü. Hemşirelik Yüksekokulu Dergisi 10:1.

20. Aslan, G. (2010) Tümör İmmünolojisi, Turk. J. Immunol. 15: 7-13.

21. Aupérin, A. et al. (1999) Prophylactic Cranial Irradiation for Patients with Small-Cell Lung Cancer in Complete Remission. New England Journal of Medicine 341: 476-484. DOI: 10.1056/NEJM199908123410703

22. Axelrad, J. E., Lichtiger, S. \& Yajnik, V. (2016) Inflammatory bowel disease and cancer: The role of inflammation, immunosuppression, and cancer treatment. World Journal of Gastroenterology 22: 4794. DOI: 10.3748/wjg. v22.i20.4794

23. Ayşe Erdogan, Aysun Özkan, (2015) Strategies to Optimize the MolecularlyTargeted Anti-Cancer Agent Combinations, Archives Medical Review Journal, Cilt 24, Sayı 4, Sayfalar 432 - 451

24. Bäck M, Ketelhuth DF, Agewall S. (2010) Matrix metalloproteinases in atherothrombosis. Prog Cardiovasc Dis.;52:410-428. DOI: 10.1016/j. pcad.2009.12.002.

25. Bailey KM. et al. (2014) Mechanisms of buffer therapy resistance. Neoplasia 16: 354-364 , 351-353. DOI: 10.1016/j.neo.2014.04.005.

26. Bainbridge, J. W et al. (2015) Long-term effect of gene therapy on Leber's congenital amaurosis. New England Journal of Medicine 372: 1887-1897. DOI: $10.1056 /$ NEJMoa1414221

27. Baker AH, Edwards DR, Murphy G. (2002) Metalloproteinase inhibitors: biological

28. Balkwill FR, Capasso M, Hagemann T. (2012) The tumor microenvironment at a glance. J Cell Sci 125: 5591-6. DOI: 10.1242/jcs.116392. 
29. Bang C, Thum T. (2012) Exosomes: new players in cell-cell communication. Int J Biochem Cell Biol; 44: 2060-4. DOI: 10.1016/j.biocel.2012.08.007.

30. Banu Atalar, Enis Özyar, (2010) Radyoterapide Teknik Gelişmeler ve IGRT (Görüntü Kılavuzluğunda Radyoterapi) Acıbadem Üniversitesi Sağlık Bilimleri Dergisi 2 .

31. Bao B. et al., (2012) Curcumin analogue CDF inhibits pancreatic tumor growth by switching on suppressor microRNAs and attenuating EZH2 expression. Cancer Res.; 72: 335-45. DOI: 10.1158/0008-5472.CAN-11-2182.

32. Bao, S. et al. (2006) Stem Cell-like Glioma Cells Promote Tumor Angiogenesis through Vascular Endothelial Growth Factor. Cancer Research 66: 7843-7848. DOI:10.1158/0008-5472.CAN-06-1010

33. Barbaros, M. B. \& Dikmen, M. (2015) Kanser immünoterapisi. Erciyes Üniversitesi Fen Bilimleri Enstitüsü Fen Bilimleri Dergisi 31: 177-182.

34. Barkan D, et al. (2010) Metastatic growth from dormant cells induced by col-I-enriched fibrotic environment. Cancer Res. 70:5706-5716. DOI: 10.1158/0008-5472.CAN-09-2356.

35. Barney LE et al . (2016) The predictive link between matrix and metastasis. Curr Opin Chem Eng 11: 85-93. DOI : 10.1016/j.coche.2016.01.001

36. Baykara, O. (2016) Current Modalities in Treatment of Cancer. Balıkesır Health Sciences Journal 5: 154-165. DOI: 10.5505/bsbd.2016.93823

37. Beitinjaneh A et al. (2015) Comparison of survival in patients with $\mathrm{T}$ cell lymphoma after autologous and allogeneic stem cell transplantation as a frontline strategy or in relapsed disease. Biol Blood Marrow Transplant 21: 855-9. DOI: 10.1016/j.bbmt.2015.01.013.

38. Beyer S. et al. (2017) The Role of miRNAs in Angiogenesis, Invasion and Metabolism and Their Therapeutic Implications in Gliomas. Cancers 9: 85. DOI: $10.3390 /$ cancers9070085.

39. Bharti R, Dey G, Mandal M. (2016) Cancer development, chemoresistance, epithelial to mesenchymal transition and stem cells: a snapshot of IL-6 mediated involvement. Cancer Lett.;375(1):51-61. DOI: 10.1016/j.canlet.2016.02.048.

40. Biosciencenotes (2018), Cytokines Son erişim: june 30, 2018 http://www. biosciencenotes.com/cytokines/

41. Bissell MJ, Hines WC. (2011) Why don't we get more cancer? A proposed role of the microenvironment in restraining cancer progression. Nat Med. 17: 320-9. DOI: $10.1038 / \mathrm{nm} .2328$

42. Bizzarri, N. et al. (2016) Bevacizumab for the treatment of cervical cancer. Expert opinion on biological therapy 16: 407-419. DOI: 10.1517/14712598.2016.1145208.

43. Blanco MA, et al. (2012) Global secretome analysis identifies novel mediators of bone metastasis. Cell Res 22: 1339-55. DOI: 10.1038/cr.2012.89. 
44. Blau HM, Brazelton TR, Weimann JM. (2001) The evolving concept of a stem cell: entity or function? Cell 105: 829-841.DOI: $10.1016 /$ S00928674(01)00409-3

45. Blick, T. et al. (2010) Epithelial Mesenchymal Transition Traits in Human Breast Cancer Cell Lines Parallel the CD44hi/CD24lo/- Stem Cell Phenotype in Human Breast Cancer. Journal of Mammary Gland Biology and Neoplasia 15: 235-252. DOI: 10.1007/s10911-010-9175-z.

46. Blomberg, O. S., Spagnuolo, L. \& Visser, K. E. D. (2018) Immune regulation of metastasis: mechanistic insights and therapeutic opportunities. Disease Models \& Mechanisms 11(10): pii: dmm036236. DOI: 10.1242/ dmm.036236.

47. Bloom, B. C. et al. (2017) Prophylactic Cranial Irradiation Following Surgical Resection of Early-Stage Small-Cell Lung Cancer: A Review of the Literature. Frontiers in Oncology 7:228. DOI: 10.3389/fonc.2017.00228.

48. Bo, H. et al. (2015) Upregulated long non-coding RNA AFAP1-AS1 expression is associated with progression and poor prognosis of nasopharyngeal carcinoma. Oncotarget 6: 20404-20418. DOI. org/10.18632/oncotarget.4057.

49. Bogachek, M. V., Andrade, J. P. D. \& Weigel, R. J.( 2014) Regulation of Epithelial-Mesenchymal Transition through SUMOylation of Transcription Factors. Cancer Research 75: 11-15 . DOI: 10.1158/0008-5472.CAN-142824.

50. Bogurcu N. et al. (2018) Analysis of hypoxia and the hypoxic response in tumor Xenografts. Methods Mol Biol. 1742: 283-300. DOI: 10.1007/978-14939-7665-2_25.

51. Bomken S, Fišer K, Heidenreich O, et al. (2010) Understanding the cancer stem cell. Br J Cancer 103: 439-445. DOI: 10.1038/sj.bjc.6605821.

52. Bonnet D, Dick JE. (1997) Human acute myeloid leukemia is organized as a hierarchy that originates from a primitive hematopoietic cell. Nat Med. 3: 730-737. DOI: 10.1038/nm0797-730

53. Boyer, B. (1989) Rearrangements of desmosomal and cytoskeletal proteins during the transition from epithelial to fibroblastoid organization in cultured rat bladder carcinoma cells. The Journal of Cell Biology 109: 14951509. DOI:10.1083/jcb.109.4.1495

54. Boyle P: (2006) The globalization of cancer. Lancet 368: 629-630. DOI:10.1016/S0140-6736(06)69225-8

55. Brabletz T . (2012) To differentiate or not--routes towards metastasis Nat Rev Cancer 12: 425-36. DOI: 10.1038/nrc3265.

56. Brabletz T, Jung A, Spaderna S, Hlubek F, Kirchner T. (2005) Opinion: migrating cancer stem cells - an integrated concept of malignant tumour progression. Nat Rev Cancer 5: 744-9. DOI:10.1038/nrc1694 
57. Brabletz T. et al., (2005) Opinion: migrating cancer stem cells - an integrated concept of malignant tumour progression. Nat Rev Cancer; 5: 744-9. DOI: $10.1038 / \mathrm{nrc1694}$

58. Brabletz, T. et al. (2005) Invasion and metastasis in colorectal cancer: epithelial-mesenchymal transition, mesenchymal-epithelial transition, stem cells and beta-catenin.Cells Tissues Organs 179: 56-65. DOI: 10.1159/000084509

59. Brabletz, T., Kalluri, R., Nieto, M. A. \& Weinberg, R. A. (2018) EMT in cancer. Nature Reviews Cancer 18: 128-134. DOI: 10.1038/nrc.2017.118

60. Bray F. et al. (2012) Global cancer transitions according to the human development index (2008-2030): a population-based study. Lancet Oncol 13: 790-801. DOI:10.1016/S1470-2045(12)70211-5

61. Brooks MD, Burness ML, Wicha MS. (2015) Therapeutic implications of cellularheterogeneity and plasticity in breast cancer. Cell Stem Cell; 17: 26071. DOI: 10.1016/j.stem.2015.08.014.

62. Brown JM, Wilson WR. (2004) Exploiting tumour hypoxia in cancer treatment. Nat Rev Cancer 4: 437-447. DOI: 10.1038/nrc1367

63. Budczies J. et al. (2015) The landscape of metastatic progression patterns across major human cancers. Oncotarget 6: 570-83. DOI:10.18632/oncotarget.2677

64. Burduk, P. K., et al.(2014). Expression of metalloproteinases 2 and 9 and tissue inhibitors 1 and 2 as predictors of lymph node metastases in oropharyngeal squamous cell carcinoma. Head \& Neck, 37(3), 418-422. DOI: 10.1002/hed.23618

65. Burotto, M., et al. (2015) Gefitinib and Erlotinib in Metastatic Non-Small Cell Lung Cancer: A Meta-Analysis of Toxicity and Efficacy of Randomized Clinical Trials. The Oncologist 20: 400-410. DOI: 10.1634/theoncologist.2014-0154.

66. Burrell, R. A., Mcgranahan, N., Bartek, J. \& Swanton, C. (2013) The causes and consequences of genetic heterogeneity in cancer evolution. $\mathrm{Na}$ ture 501: 338-345. DOI: 10.1038/nature12625.

67. Byung, S. (1996) Vascular thermal adaptation in tumors and normal tissue in rats. International Journal of Radiation Oncology ${ }^{\star}$ Biology ${ }^{\star}$ Physics 35: 95-101. DOI.;/10.1016/S0360-3016(96)85016-4

68. C. Amălinei, et al.(2010), Matrix metalloproteinases involvement in pathologic conditions Rom. J. Morphol. Embryol., 51 (2) pp. 215-228

69. Cameron MD, et al. (2000) Temporal progression of metastasis in lung: cell survival, dormancy, and location dependence of metastatic inefficiency. Cancer Res. 60:2541-2546.

70. Cancer: Impact and Challenges NIH (https://stemcells.nih.gov/info/Regenerative_Medicine/2006chapter9.htm)

71. Canel M, (2013) E-cadherin-integrin crosstalk in cancer invasion and metastasis. J Cell Sci 126: 393-401. DOI: 10.1242/jcs.100115. 
72. Cantor JR, Sabatini DM. (2012) Cancer cell metabolism: One hallmark, many faces. Cancer Discov 2: 881-898. DOI: 10.1158/2159-8290.CD-12-0345.

73. Cao Q, et al. (2018) Macrophages as a potential tumor-microenvironment target for noninvasive imaging of early response to anticancer therapy. Biomaterials 152: 63-76. DOI: 10.1016/j.biomaterials.2017.10.036.

74. Capozzi, M. et al. (2015) Everolimus and pancreatic neuroendocrine tumors (PNETs): Activity, resistance and how to overcome it. International Journal of Surgery 21: S89-94. DOI: 10.1016/j.ijsu.2015.06.064.

75. Carmeliet P. (2005) VEGF as a key mediator of angiogenesis in cancer. Oncology 69: 4-10. DOI : 10.1159/000088478

76. Carmeliet P. et al. (1998) Role of HIF-1 $\alpha$ in hypoxia-mediated apoptosis, cell proliferation and tumor angiogenesis. Nature 394: 485. DOI:10.1038/28867

77. Carmeliet, P., and Jain, R.K. (2000) Angiogenesis in cancer and other diseases. Nature 407: 249-257 DOI: 10.1038/35025220

78. Carroll T, Ladner K, Meyers AD. (2005) Alternative surgical dissection techniques. Otolaryngol Clin N Am 38: 397-411. DOI: 10.1016/j. otc.2004.10.001.

79. Carter, Paul. (2001) "Improving the Efficacy of Antibody-Based Cancer Therapies." Nature Reviews Cancer, vol. 1, no. 2, pp. 118-129., DOI:10.1038/35101072.

80. Chaffer, C. L. \& Weinberg, R. A. A (2011) Perspective on Cancer Cell Metastasis. Science 331:1559-1564. DOI: 10.1126/science. 1203543

81. Chambers AF, Groom AC, MacDonald IC. (2002) Dissemination and growth of cancer cells in metastatic sites. Nat Rev Cancer 2: 563-572. DOI: $10.1038 / \mathrm{nrc} 865$

82. Chen F, et al. (2015) New horizons in tumor microenvironment biology: challenges and opportunities. BMC medicine. 13: 45. DOI: 10.1186/s12916015-0278-7.

83. Chen, L. \& Flies, D. B. (2013) Erratum: Molecular mechanisms of T cell co-stimulation and co-inhibition. Nature Reviews Immunology 13: 542542. DOI: $10.1038 /$ nri3405.

84. Chen, L.-S. et al. (2012) A new prospect in cancer therapy: targeting cancer stem cells to eradicate cancer. Chinese Journal of Cancer 31: 564-572. DOI: $10.5732 /$ cjc.011.10444

85. Chen, Y., Tan, W. \& Wang, C. (2018) Tumor-associated macrophage-derived cytokines enhance cancer stem-like characteristics through epithelial-mesenchymal transition. OncoTargets and Therapy 11: 3817-3826. DOI: 10.2147/OTT.S168317.

86. Cheng, H. et al. (2018) Performance of Harmonic devices in surgical oncology: an umbrella review of the evidence. World Journal of Surgical Oncology 16: 2 DOI: 10.1186/s12957-017-1298-x. 
87. Cheong HT et al. (2003) Cell cycle analysis of bovine cultured somatic cells by flow cytometry. Jpn J Vet Res. 51: 95-103. DOI:10.14943/jjvr.51.2.95

88. Cheung, T. H. \& Rando, T. A. (2013) Molecular regulation of stem cell quiescence. Nature Reviews Molecular Cell Biology 14: 329-340. DOI: 10.1038/nrm3591.

89. Chiba T, Kita K, Zheng YW, et al. (2006) Side population purified from hepatocellular carcinoma cells harbors cancer stem cell -like properties. Hepatology 44: 20-251. DOI: 10.1002/hep.21227

90. Chlebowski RT. et al. (2013) Estrogen plus progestin and breast cancer incidence and mortality in the Women's Health Initiative Observational Study. J Natl Cancer Inst 105: 526-35. DOI: 10.1093/jnci/djt043.

91. Cho DY.etal. (2013) Targeting cancer stem cells for treatment of glioblastoma multiforme. Cell Transplant 22: 731-9 . DOI: 10.3727/096368912X655136.

92. Chou J, Shahi P, Werb Z. (2013) microRNA-mediated regulation of the tumor microenvironment. Cell cycle 12: 3262-71. DOI: 10.4161/cc.26087.

93. Christiansen, J.J. and Rajasekaran, A.K. (2006) Reassessing epithelial to mesenchymal transition as a prerequisite for carcinoma invasion and metastasis. Cancer Res 66: 8319-8326. DOI: 10.1158/0008-5472.CAN-06-0410

94. Clark A.G., Vignjevic D.M. (2015) Modes of cancer cell invasion and the role of the microenvironment. Curr. Opin. Cell Biol 36: 13-22. DOI: 10.1016/j.ceb.2015.06.004.

95. Clarke MF et al. (2006) Cancer stem cells-perspectives on current status and future directions: AACR workshop on cancer stem cells. Cancer Res. 66: 9339-44. DOI:10.1158/0008-5472.CAN-06-3126

96. Clarke MF, Fuller M. (2006) Stem cells and cancer: two faces of eve. Cell; 124: 1111-5. DOI:10.1016/j.cell.2006.03.011

97. Corallino, S., Malabarba, M. G., Zobel, M., Fiore, P. P. D. \& Scita, G. (2015) Epithelial-to-Mesenchymal Plasticity Harnesses Endocytic Circuitries. Frontiers in Oncology 5: 45. DOI: 10.3389/fonc.2015.00045.

98. Cortini M, Massa A, Avnet S, Bonuccelli G, Baldini N. (2016) Tumor-activated mesenchymal stromal cells promote osteosarcoma stemness and migratory potential via IL-6 secretion. PLoS ONE. 11(11):e0166500. DOI: 10.1371/journal.pone.0166500.

99. Craddock R B et al., (1999) An Intervention to increase use and effecetiveness of selfcare measures for breast cancerchemotherapy patients, Cancer Nursing 22: 312-319. DOI: 10.1097/00002820-199908000-00009

100. Craene, B. D. \& Berx, G. (2013) Regulatory networks defining EMT during cancer initiation and progression. Nature Reviews Cancer 13: 97-110. DOI: $10.1038 / \mathrm{nrc} 3447$.

101. Crivellato, E. \& Ribatti, D. (2009) Recent Advances in Angiogenesis and Antiangiogenesis 30-39. DOI: 10.2174/97816080500481090101 
102. Culver, K. W. et al. (1991) Correction of ADA deficiency in human T lymphocytes using retroviral-mediated gene transfer. Transplantation proceedings. 23: No. 1 Pt 1. PMID:1846711

103. Cyr, A. R. et al. (2014) TFAP2C governs the luminal epithelial phenotype in mammary development and carcinogenesis. Oncogene 34: 436-444. DOI: 10.1038/onc.2013.569.

104. Czubaty, A. \& Piekiełko-Witkowska, A. (2017) Protein kinases that phosphorylate splicing factors: Roles in cancer development, progression and possible therapeutic options. The International Journal of Biochemistry \& Cell Biology 91: 102-115. DOI: 10.1016/j.biocel.2017.05.024.

105. Çağrı ŞAKALAR, Kenan İZGİ, Halit CANATAN, (2013) Kanser İmmün Terapi veMonoklonal Antikorlar, Fırat Üniversitesi Sağlık Bilimleri Tıp Dergisi, , Cilt 27, Sayı 2, Sayfa(lar) 105-110.

106. Dalerba P, Cho RW, Clarke MF. (2007) Cancer stem cells: models and concepts. Annu Rev Med. 58: 267-284 .DOI: 10.1146/annurev. med.58.062105.204854

107. Daley, G. Q. (2003) Realistic Prospects for Stem Cell Therapeutics. Hematology 398-418 DOI:10.1182/asheducation-2003.1.398

108. Davies C. et al. (2011) Early Breast Cancer Trialists Collaborative Group Relevance of breast cancer hormone receptors and other factors to the efficacy of adjuvant tamoxifen patient-level meta-analysis of randomized trials. Lancet. 378: 771-784. DOI: 10.1016/S0140-6736(11)60993-8.

109. Dawson LA, Jaffray DA. (2007) Advances in image-guided radiation therapy. J Clin Oncol 25: 938-946. DOI:10.1200/JCO.2006.09.9515

110. Dawson LA, Sharpe MB. (2006) Image-guided radiotherapy: rationale, benefits, and limitations. Lancet Oncol 7: 848-858. DOI: 10.1016/S14702045(06)70904-4

111. Decock J., et al.(2011) Matrix metalloproteinases: protective roles in cancer. Journal of Cellular and Molecular Medicine. 15(6):1254-1265. DOI: 10.1111/j.1582-4934.2011.01302.x.

112. Delaney, G., et al., (2005) Role of radiotherapy in cancer treatment. Cancer 104: 1129-1137. DOI: 10.1002 / cncr.21324. DOI: 10.1038 / nrclinonc.2012.194.

113. Demirelli, F. H. (2005) Hedefe yönelik kanser tedavisi ve monoklonal antikorlar. Antibiyotik ve Kemoterapi Derneği (ANKEM) Dergisi, 19: 123125.

114. Demuth, P. C. et al. (2013) Polymer multilayer tattooing for enhanced DNA vaccination. Nature Materials 12: 367-376. DOI: 10.1038/nmat3550

115. Deonarain MP, Kousparou CA, Epenetos AA. (2009) Antibodies targeting cancer stem cells: a new paradigm in immunotherapy? MAbs1: 12-25. DOI:10.4161/mabs.1.1.7347 
116. Deryugina EI, Quigley JP. (2006) Matrix metalloproteinases and tumor metastasis. Cancer Metastasis Rev. 25:9-34. DOI: 10.1007/s10555-006-7886-9.

117. Deshmukh, A., et al., (2016) Cancer stem cell metabolism: a potential target for cancer therapy. Molecular;15: 69. DOI:10.1186/s12943-016-0555-X

118. Devassy R, Gopalakrishnan S, De Wilde RL. (2015) Surgical efficacy among laparoscopic ultrasonic dissectors: are we advancing safely? A review of literature. J Obstet Gynaecol India 65: 293-300. DOI: 10.1007/ s13224-015-0774-x.

119. DeVita VT, Serpick AA, Carbone PP. (1970) Combination chemotherapy in the treatment of advanced Hodgkin's disease. Ann Intern Med 73: 881-95.

120. DeVita VT. (1971) Cell kinetics and the chemotherapy of cancer. Cancer Chemother Rep 2: 23-33. DOI: 10.1158/0008-5472.CAN-07-6611

121. Devita, V. T. \& Chu, E. (2008) A History of Cancer Chemotherapy. Cancer Research 68, 8643-8653 DOI: 10.1158/0008-5472.CAN-07-6611.

122. Devita, V. T. (1974) BCG Vaccine Treatment of Hodgkin Disease. JAMA: The Journal of the American Medical Association 228: 28. DOI:10.1001/ jama.1974.03230260022015

123. DNA damage by reactive oxygen species (ROS) and its biological consequences http://www.staff.uni-mainz.de/epe/AK-forschung\%20eng.htm erişim:30.06.2019

124. Draoui N. et al. (2013) Synthesis and pharmacological evaluation of carboxycoumarins as a new antitumor treatment targeting lactate transport in cancer cells. Bioorg Med Chem 21: 7107-7117. DOI: 10.1016/j. bmc.2013.09.010.

125. Drevs, J., et al., (1999) "Phase I Dose Escalation, Pharmacokinetic (Pk) Study of a Novel Vascular Endothelial Growth Factor (VEGF) Receptor Inhibitor, PTK787/ZK 222584 (PTK/ZK)." European Journal of Cancer, 35 DOI:10.1016/s0959-8049(99)81557-3.

126. Du J, Lane LA, Nie S. (2015) Stimuli-responsive nanoparticles for targeting the tumor microenvironment. J Control Release 219: 205. DOI: 10.1016/j. jconrel.2015.08.050.

127. Ell B, et al. (2013) Tumor-Induced Osteoclast miRNA Changes as Regulators and Biomarkers of Osteolytic Bone Metastasis. Cancer Cell 24: 542556. DOI: 10.1016/j.ccr.2013.09.008.

128. Elloumi J, et al., (2012) Monoclonal antibodies as cancer therapeutics. Recent Pat Biotechnol. 6: 45-56.

129. Engür, S. \& Dikmen, M. (2015) Kanser tedavisinde proteozom inhibitörlerinin önemi. Erciyes Üniversitesi Fen Bilimleri Enstitüsü Fen Bilimleri Dergisi 31: 182-190.

130. Eramo A, Haas TL, De Maria R. (2010) Lung cancer stem cells: tools and targets to fight lung cancer. Oncogene 29: 4625 -4635. DOI: 10.1038/ onc.2010.207. 
131. Eriksson, D. \& Stigbrand, T. (2010) Radiation-induced cell death mechanisms. Tumor Biology 31: 363-372. DOI: 10.1007 / s13277-010-0042-8. DOI: $10.1007 / \mathrm{s} 13277-010-0042-8$.

132. Esquela-Kerscher A, Slack FJ. (2006) Oncomirs - MicroRNAs with a role in cancer. Nat Rev Cancer 6: 259-269. DOI: 10.1038/nrc1840

133. Evans M. (2011) Discovering pluripotency: 30 years of mouse embryonic stem cells. Nat Rev Mol Cell Biol; 12: 680-6. DOI: 10.1038/nrm3190.

134. Fan F, et al. (2012) Overexpression of snail induces epithelial-mesenchymal transition and a cancer stem cell-like phenotype in human colorectal cancer cells. Cancer Med 1:5-16. DOI: 10.1002/cam4.4.

135. Fang H, Declerck YA. (2013) Targeting the tumor microenvironment: from understanding pathways to effective clinical trials. Cancer Res. 73: 4965-4977. DOI: 10.1158/0008-5472. CAN-13-0661

136. Fang TC. et al. (2004) Adult stem cell plasticity: will engineered tissues be rejected? Int J Exp Pathol. 85: 115-124. DOI: 10.1111/j.09599673.2004.00380.x

137. Fang, Y. et al. (2018) Doxorubicin-loaded dextran-based nano-carriers for highly efficient inhibition of lymphoma cell growth and synchronous reduction of cardiac toxicity. International Journal of Nanomedicine Volume 13: 5673-5683. DOI: 10.2147/IJN.S161203.

138. Fearon ER, Vogelstein B. (1990) A genetic model for colorectaltumorigenesis. Cell 61: 759-67. DOI.org/10.1016/0092-8674(90)90186-I

139. Fidler IJ. (2003) The pathogenesis of cancer metastasis: The 'seed and soil' hypothesis revisited. Nat Rev Cancer 3: 453-458. DOI: 10.1038/nrc1098.

140. Fidler, M. M., Bray, F. \& Soerjomataram, I. (2017) The global cancer burden and human development: A review. Scandinavian Journal of Public Health 46: 27-36. DOI: 10.1177/1403494817715400.

141. Folkman J , et al., (1971) Isolation of a tumor factor responsible for angiogenesis. J. Exp. Med 133: 275-288. DOI : 10.1084/jem.133.2.275

142. Folkman J, Long DM, Becker FF. (1963) Growth and metastasis of tumor in organ culture. Cancer 16: 453-67. DOI.org/10.1002/1097-0142

143. Folkman, J. (2006) Angiogenesis. Annual Review of Medicine 57: 1-18. DOI: 10.1146/annurev.med.57.121304.131306

144. Fonseca KB et al. (2011) Molecularly designed alginate hydrogels susceptible to local proteolysis as three-dimensional cellular microenvironments. Acta Biomater. $4: 1674-82$. DOI: 10.1016/j.actbio.2010.12.029.

145. Fontana, F., et al., (2016) Delivery of therapeutics with nanoparticles: whats new in cancer immunotherapy? Wiley Interdisciplinary Reviews: Nanomedicine and Nanobiotechnology 9: e1421 DOI: 10.1002/wnan.1421.

146. Francescone R, Hou V, Grivennikov S , (2015) Cytokines, IBD, and colitis-associated cancer. Inflamm Bowel Dis. 21: 409-18. DOI: 10.1097/ MIB.0000000000000236. 
147. Frankland-Searby, S., Bhaumik, R.S. (2012) The 26S proteasome complex: An attractive target for cancer therapy. Biochimica. et Biophysica. Acta.; 1825: 64-76. DOI: 10.1016/j.bbcan.2011.10.003.

148. Fridman WH, et al. (2017) The immune contexture in cancer prognosis and treatment. Nat Rev Clin Oncol. 14: 717-34. DOI: 10.1038/nrclinonc.2017.101.

149. Friedl P, Alexander S. (2011) Cancer invasion and the microenvironment: plasticity and reciprocity. Cell. 147: 992-1009. DOI: 10.1016/j. cell.2011.11.016.

150. Friedl P., Wolf K. (2003) Tumour-cell invasion and migration: diversity and escape mechanisms. Nat. Rev. Cancer 3: 362-374. DOI : 10.1038/nrc1075

151. Fuat H.DEMİRELLİ, (2005), Monoclonal Antibodies for Targeted Cancer Therapy,

152. Fujita S, Kotake K. (2014) Chemotherapy Nihon Rinsho 72: 102-7. PMID:24597356

153. G. Murphy, H. Nagase (2008) Progress in matrix metalloproteinase research Mol. Aspects Med., 29 (5) pp. 290-308

154. Gabrilovich DI, Nagaraj S. (2009) Myeloid-derived suppressor cells as regulators of the immune system. Nat Rev Immunol. 9: 162-174. DOI: 10.1038/nri2506.

155. Gandalovičová, A. et al. (2017) Migrastatics-Anti-metastatic and Anti-invasion Drugs: Promises and Challenges. Trends in Cancer 3: 391406. DOI: 10.1016/j.trecan.2017.04.008.

156. Gao, J.-X. (2007) Stem Cells Review Series: Cancer stem cells: the lessons from pre-cancerous stem cells. Journal of Cellular and Molecular Medicine ; 12: 67-96. DOI:10.1111/j.1582-4934.2007.00170.x

157. Gerlinger, M. et al. (2014) Cancer: Evolution Within a Lifetime. Annual Review of Genetics 48: 215-236. DOI: 10.1146/annurev-genet-120213-092314.

158. Gerlinger, M. et al., (2014) Cancer: Evolution Within a Lifetime. Annual Review of Genetics 48: 215-236. DOI: 10.1146/annurev-genet-120213-092314.

159. Ghobrial, I.M., Witzig, T.E., Adje1, A.A. (2005) Targeting apoptosis pathways in cancer therapy. CA Cancer J. Clin. 55: 178-194. 10.3322/canjclin.55.3.178

160. Gilbert CA, Ross AH. (2009) Cancer stem cells: cell culture, markers, and targets for new therapies. J Cell Biochem 108: 1031-1038. DOI: 10.1002/ jcb. 22350 .

161. Gillis N.K., McLeod H.L. (2016) The pharmacogenomics of drug resistance to protein kinase inhibitors. Drug Resist. Updat. 28: 28-42. DOI: 10.1016/j. drup.2016.06.008. 
162. Giordano, P. et al. (2016) Afatinib: An overview of its clinical development in non-small-cell lung cancer and other tumors. Critical Reviews in Oncology/Hematology 97: 143-151. DOI: 10.1016/j.critrevonc.2015.08.016.

163. Gkretsi, V. \& Stylianopoulos, T. (2018) Cell Adhesion and Matrix Stiffness: Coordinating Cancer Cell Invasion and Metastasis. Frontiers in Oncology 8:145. DOI: 10.3389/fonc.2018.00145.

164. Global Burden of Disease Collaborative Network (2016). Global Burden of Disease Study (GBD 2016) Results. Seattle, United States: Institute for Health Metrics and Evaluation (IHME), 2017. https://ourworldindata.org/ causes-of-death

165. Gong, Y.-F. et al. (2017) Optimized construction of MUC1-VNTRn DNA vaccine and its anti-pancreatic cancer efficacy. Oncology Letters 13: 21982206. DOI: 10.3892/ol.2017.5717.

166. Gonzalez, D. M. \& Medici, D. (2014) Signaling mechanisms of the epithelial-mesenchymal transition. Science Signaling 7:re8. DOI: 10.1126/ scisignal.2005189.

167. Gonzalez-Avila, et al., (2019). Matrix metalloproteinases participation in the metastatic process and their diagnostic and therapeutic applications in cancer. Critical Reviews in Oncology/Hematology, 137, 57-83. DOI:10.1016/j.critrevonc.2019.02.010

168. Gorby, C., Martinez-Fabregas, J., Wilmes, S., \& Moraga, I. (2018). Mapping Determinants of Cytokine Signaling via Protein Engineering. Frontiers in Immunology, 9. DOI: 10.3389/fimmu.2018.02143

169. Granchi C, Fancelli D, Minutolo F. (2014) An update on therapeutic opportunities offered by cancer glycolytic metabolism. Bioorg Med Chem Lett 24: 4915-4925. DOI: 10.1016/j.bmcl.2014.09.041.

170. Greenburg G, Hay ED. (1982) Epithelia suspended in collagen gels can lose polarity and express characteristics of migrating mesenchymal cells. J Cell Biol 95: 333-9. DOI: 10.1083/jcb.95.1.333

171. Groom AG, Younis T. (2016) Endocrine therapy for breast cancer prevention in high-risk women: clinical and economic considerations. Expert Rev Pharmacoecon Outcomes ResMar 17: 1-11. DOI: 10.1586/14737167.2016.1159514.

172. Gross J, Lapiere CM. (1962) Collagenolytic Activity in Amphibian Tissues: a Tissue Culture Assay. Proc Natl Acad Sci U S A.;48(6):1014-22.

173. Grunert, S., Jechlinger, M. and Beug, H. (2003) Diverse cellular and molecular mechanisms contribute to epithelial plasticity and metastasis. Nat. Rev. Mol. Cell. Biol 4: 657-665. DOI: 10.1038/nrm1175.

174. Guarino M, Rubino B, Ballabio G. (2007) The role of epithelial-mesenchymal transition in cancer pathology. Pathology. 39:305-318. DOI:10.1080/00313020701329914 
175. Gucciardo L, et al. (2009) Fetal mesenchymal stem cells: isolation, properties and potential use in perinatology and regenerative medicine. BJOG 116: 166-172 . DOI: 10.1111/j.1471-0528.2008.02005.x.

176. Guo W. et al. (2017) Exosomes: New players in cancer. Oncology Reports 38: 665-75. DOI: 10.3892/or.2017.5714.

177. Gupta, G. P. \& Massagué, J. (2006) Cancer Metastasis: Building a Framework. Cell 127: 679-695. DOI : 10.1016/j.cell.2006.11.001

178. Hamid O. (2004) Emerging treatments in oncology: focus on tyrosine kinase (erbB) receptor inhibitors. J Am Pharm Assoc; 44: 52-8.

179. Hanahan, D. \& Weinberg, R. A. (2000) The hallmarks of cancer. Oxford Medicine Online 100: 57-70. DOI.org/10.1002/9781119000822.hfcm002

180. Hanahan, D. \& Weinberg, R. A. Hallmarks of Cancer: The Next Generation. Cell 2011; 144: 646-674. DOI:https://DOI.org/10.1016/j. cell.2011.02.013

181. Harris, T. J. \& Drake, C. G. (2013) Primer on tumor immunology and cancer immunotherapy. Journal for ImmunoTherapy of Cancer 1:12. DOI: 10.1186/2051-1426-1-12.

182. Hawsawi, Y. M. et al. (2018) Stem Cell Applications for Treatment of Cancer and Autoimmune Diseases: Its Promises, Obstacles, and Future Perspectives. Technology in Cancer Research \& Treatment 17: 153303381880691. DOI: $10.1177 / 1533033818806910$

183. Hay ED. (1995) An overview of epithelio-mesenchymal transformation. Acta Anat(Basel) 154: 8-20. DOI:10.1159/000147748

184. He G, , et al. (2013) Identification of liver cancer progenitors whose malignant progression depends on autocrine IL-6 signaling. Cell.;155(2):384396. DOI: 10.1016/j.cell.2013.09.031.

185. He L, et al. (2005) A microRNA polycistron as a potential human oncogene. Nature 435, 828-833. DOI: 10.1038/nature03552

186. Heiden, M. G. V., Cantley, L. C. \& Thompson, C. B. (2009) Understanding the Warburg Effect: The Metabolic Requirements of Cell proliferation. Science 324: 1029-1033. DOI: 10.1126/science.1160809.

187. Hemmatzadeh, M., et al., (2016) The role of oncomirs in the pathogenesis and treatment of breast cancer. Biomedicine \& Pharmacotherapy 78: 129-139. DOI: 10.1016/j.biopha.2016.01.026.

188. Henderson, T. et al. (2018) Alterations in cancer stem-cell marker CD44 expression predict oncologic outcome in soft-tissue sarcomas. Journal of Surgical Research 223: 207-214. DOI: 10.1016/j.jss.2017.11.016.

189. Hendriks LE. et al. (2016) Effect of Bisphosphonates, Denosumab, and Radioisotopes on Bone Pain and Quality of Life in Patients with Non-Small Cell Lung Cancer and Bone Metastases: A Systematic Review. J Thorac Oncol 11: 155-73. DOI: 10.1016/j.jtho.2015.10.001. 
190. Henze, A.-T. \& Mazzone, M. (2016) The impact of hypoxia on tumor-associated macrophages. Journal of Clinical Investigation 126: 3672-3679. DOI: $10.1172 /$ JCI84427.

191. Hewitt HB. (1953) Studies of the quantitative transplantation of Mouse sarcoma. Br J Cancer; 7: 367-383. DOI.org/10.1038/bjc.1953.35

192. Hoogsteen IJ, et al. (2007) Tumor microenvironment in head and neck squamous cell carcinomas: Predictive value and clinical relevance of hypoxicmarkers. A review. Head Neck 29: 591-604. DOI: 10.1002/hed.20543

193. Hope KJ, Jin L, Dick JE. (2004) Acute myeloid leukemia originates from a hierarchy of leukemic stem cell classes that differ in self-renewal capacity. Nat Immunol. 5: 738-743. DOI:10.1038/ni1080

194. Horizons in Cancer Research (2015) vol.57. Current Therapies and Latest Developments in Cancer Treatment, s.105-156, Editor: Watanabe, Hiroto S. Nova Science Publishers, New York, ABD. ISBN: 978-1-63482-498-9

195. http://www.sinobiological.com/Role-of-Cytokines-in-cancer.html

196. Hu XX, et al. (2004) Expression of matrix metalloproteinases-9,2,7, and tissue inhibitor of metalloproteinases-1,2,3 mRNA in ovarian tumors and their clinical significance. Ai Zheng.;23:1194-1198.

197. Huang M. et al. (2016) Regulation of COX-2 expression and epithelial-to-mesenchymal transition by hypoxia-inducible factor-1alpha is associated with poor prognosis in hepatocellular carcinoma patients post TACE surgery. International journal of oncology 48: 2144-54 . DOI: 10.3892/ ijo.2016.3421.

198. Hughes, P. E., Caenepeel, S. \& Wu, L. C. (2016) Targeted Therapy and Checkpoint Immunotherapy Combinations for the Treatment of Cancer. Trends in Immunology 37: 462-476. DOI: 10.1016/j.it.2016.04.010.

199. Hui L, Chen Y. (2015) Tumor microenvironment: Sanctuary of the devil. Cancer Lett. 368: 7-13. DOI: 10.1016/j. canlet.2015.07.039.

200. Hui L, Chen Y. (2015) Tumor microenvironment: Sanctuary of the devil. Cancer letters. 368: 7-13. DOI: 10.1016/j.canlet.2015.07.039.

201. Huntly BJP, Gilliland DG. (2005) Leukemia stem cells and the evolution of cancer stem cells. Nat Rev Cancer 5: 311-321. DOI:10.1038/nrc1592

202. Hurkmans CW. et al., (2001) Set-up verification using portal imaging; review of current clinical practice Radiother Oncol 58: 105-20. 10.1016/ s0167-8140(00)00260-7

203. Iamshanova, O., Pla, A. F. \& Prevarskaya, N. (2017) Molecular mechanisms of tumour invasion: regulation by calcium signals. The Journal of Physiology 595: 3063-3075. DOI: 10.1113/JP272844.

204. Illés, Á., Jóna, Á., \& Miltényi, Z. (2015) Brentuximab vedotin for treating Hodgkin's lymphoma: an analysis of pharmacology and clinical efficacy. Expert opinion on drug metabolism \& toxicology, 11: 451-459. DOI: $10.1517 / 17425255.2015 .1007950$. 
205. Inacio Pinto $\mathrm{N}$ et al. (2015) Cancer as a Proinflammatory Environment: Metastasis and Cachexia. Mediators of inflammation. 2015, 791060. DOI: $10.1155 / 2015 / 791060$.

206. Ivey JW, et al., (2016) Improving cancer therapies by targeting the physical and chemical hallmarks of the tumor microenvironment. Cancer letters. 380: 330-9. DOI: 10.1016/j.canlet.2015.12.019.

207. Iyer, S. P. \& Foss, F. F. (2015) Romidepsin for the Treatment of Peripheral T-Cell Lymphoma. The Oncologist 20: 1084-1091. DOI: 10.1634/theoncologist.2015-0043.

208. Jacob A, et al. (2015) The regulation of MMP targeting to invadopodia during cancer metastasis. Front Cell Dev Biol 3: 4. DOI: 10.3389/ fcell.2015.00004.

209. Jacob A, Prekeris R, Kaverina I \& Roger S (2015) The regulation of MMP targeting to invadopodia during cancer metastasis. Front Cell Dev Biol 3: 4. DOI: 10.3389/fcell.2015.00004.

210. Jaffray, D. A. (2012) Image-guided radiotherapy: from current concept to future perspectives. Nature Reviews Clinical Oncology 9: 688-699. DOI: 10.1038/nrclinonc.2012.194.

211. Jain RK. (2005) Normalization of tumor vasculature: an emerging concept in antiangiogenic therapy. Science 307: 58-62. DOI: $10.1126 /$ science. 1104819

212. Jang H, Yang J, Lee E, Cheong JH. (2015) Metabolism in embryonic and cancer stemness. Arch Pharm Res. 38: 381-8. DOI: 10.1007/s12272-0150558-y.

213. Jang M, Kim SS, Lee J. (2013) Cancer cell metabolism: Implications for therapeutic targets. Exp Mol Med. 45: e45. DOI: 10.1038/emm.2013.85

214. Janiszewska, M. \& Polyak, K. (2015) Clonal Evolution in Cancer: A Tale of Twisted Twines. Cell Stem Cell , 16: 11-12. DOI: 10.1016/j. stem.2014.12.011.

215. Janssen HL. et al. (2005) Hypoxia in head and neck cancer: How much, how important? Head Neck 27: 622-38. DOI: 10.1002/hed.20223

216. Jiang C, et al. (2017) Mesenchymal stromal cell-derived IL-6 promotes epithelial-mesenchymal transition and acquisition of epithelial stem-like cell properties in ameloblastoma epithelial cells. Stem Cells. 35: 20832094. DOI: $10.1002 /$ stem.2666.

217. Jiang X. et al. (2017) Exosomal microRNA remodels thetumor microenvironment. PeerJ. 5: e4196. DOI: 10.7717/peerj.4196.

218. Jiang, J.-H. et al. (2015) Epithelial-mesenchymal transition in pancreatic cancer: Is it a clinically significant factor? Biochimica et Biophysica Acta (BBA) - Reviews on Cancer 1855: 43-49. DOI.org/10.1016/j.bbcan.2014.11.004 
219. Jiawei T. et al. (2018) Ultrasound-mediated microbubble destruction: a new method in cancer immunotherapy. Onco Targets Ther 11: 5763-5775. DOI: 10.2147/OTT.S171019

220. Jin, F. et al. (2018) Cancer risk assessment in modern radiotherapy workflow with medical big data. Cancer Management and Research Volume 10: $1665-1675$.

221. Jordan CT, Guzman ML, Noble M. (2006) Cancer stem cells. N EnglJ Med. 355: 1253-1261. DOI:10.1056/NEJMra061808

222. Jordan MA, Wilson (2004) Microtubules as a target for anticancer drugs. Nat Rev Cancer 4: 253-265. DOI: 10.1038/nrc1317.

223. Joyce JA, Pollard JW. (2009) Microenvironmental regulation of metastasis. Nat Rev Cancer 9: 239-252. DOI: 10.1038/nrc2618.

224. Jung YW, et al., (2012) Human induced pluripotent stem cells and neurodegenerative disease: prospects for novel therapies. Curr Opin Neurol 25: 125-30. DOI: 10.1097/WCO.0b013e3283518226.

225. Justus CR, Sanderlin EJ, Yang LV. (2015) Molecular Connections between Cancer Cell Metabolism and the Tumor Microenvironment. International journal of molecular sciences. 16: 11055-86. DOI: 10.3390/ijms160511055

226. Kahlert C, Kalluri R. (2013) Exosomes in tumor microenvironment influence cancer progression and metastasis. Journal of molecular medicine 91: 431-7. DOI: 10.1007/s00109-013-1020-6.

227. Kalluri R, Neilson EG (2003) Epithelial-mesenchymal transition and its implications for fibrosis. J Clin Invest ; 112: 1776. DOI: 10.1172/JCI20530

228. Kalluri R, Weinberg RA. (2009) The basics of epithelial-mesenchymal transition J Clin Invest 119: 1420-8. DOI:10.1172/JCI39104

229. Kalluri R. (2009) EMT: when epithelial cells decide to become mesenchymal-like cells. J Clin Invest. 119: 1417-419 . DOI: 10.1172/JCI39675.

230. Kalluri, R. \& Weinberg, R. A. (2010) The basics of epithelial-mesenchymal transition. Journal of Clinical Investigation 120: 1786-1786. DOI: 10.1172/JCI39104

231. Kaplan RN, et al. (2015) VEGFR1-positive haematopoietic bone marrow progenitors initiate the pre-metastatic niche. Nature 438: $820-827$. DOI : 10.1038 /nature 04186

232. Karsten U, Goletz S. (2013) What makes cancer stem cell markers different? Springerplus;2: 301. DOI: 10.1186/2193-1801-2-301

233. Keating MJ, Flinn I, Jain V et al (2002) Therapeutic role of alemtuzumab (Campath-1H) in patients who have failed fludarabine: results of a large international study, Blood;99:3554-61

234. Kennedy J. et al. (1999) Recent innovations in bipolar electrosurgery. Minim Invasive Ther Allied Technol. 8: 95-99. DOI: 10.3109/13645709909153141.

235. Kessenbrock K, Plaks V, Werb Z. (2010) Matrix metalloproteinases: regulators of the tumor microenvironment. Cell 141: 52-67. DOI: $10.1016 / \mathrm{j}$. cell.2010.03.015. 
236. Khan, M., et al., (2015) H. Role of Epithelial Mesenchymal Transition in Prostate Tumorigenesis. Current Pharmaceutical Design 21: 1240-1248. DOI:10.2174/1381612821666141211120326.

237. Kinhikar RA. et al. (2014) Rapid Arc, helical tomotherapy, sliding window intensity modulated radiotherapy and three dimensional conformal radiation for localized prostate cancer: a dosimetric comparison. J Cancer Res Ther 10: 575-82. DOI: 10.4103/0973-1482.138200.

238. Klein T., (2011) Bischoff R. Physiology and pathophysiology of matrix metalloproteases. Amino Acids.;41:271-290. DOI: 10.1007/s00726-0100689-x.

239. Klemm F, Joyce JA. (2015) Microenvironmental regulation of therapeutic response in cancer. Trends Cell Biol. 25: 198-213. DOI: 10.1016/j. tcb.2014.11.006.

240. Klimanskaya, I., Chung, Y., Becker, S., Lu, S.-J. \& Lanza, R. (2006) Human embryonic stem cell lines derived from single blastomeres. Nature 444: 481-485. DOI:10.1038/nature05142

241. Knudson AG Jr, Strong LC, Anderson DE. (1973) Heredity and cancer in man.Prog MedGenet.; 9: 113-58.DOI: 10.1001/jama.1943.02840270035014

242. Knudson AG. (1996) Hereditary cancer: two hits revisited. J Cancer Res Clin Oncol. 122: 135-40. DOI:10.1007/BF01366952

243. Kochanek, D. M., et al., ( 2018) Complementing Cancer Metastasis. Frontiers in Immunology9: 1629. DOI: 10.3389/fimmu.2018.01629

244. Koff, W. C. et al. (2013) Accelerating Next-Generation Vaccine Development for Global Disease Prevention. Science 340: 1232910-1232910. DOI: $10.1126 /$ science. 1232910

245. Kondaveeti Y, et al., (2015) Epithelial-mesenchymal transition induces similar metabolic alterations in two independent breast cancer cell lines. Cancer Lett 364: 44-58 . DOI: 10.1016/j.canlet.2015.04.025.

246. Korkaya H, Liu S, Wicha MS. (2011) Breast cancer stem cells, cytokine networks, and the tumor microenvironment. J Clin Invest.;121(10):3804-3809. DOI: $10.1172 /$ JCI57099.

247. Korpal M, et al. (2008) The miR-200 family inhibits epithelial-mesenchymal transition and cancer cell migration by direct targeting of E-cadherin transcriptional repressors ZEB1 and ZEB2. J Biol Chem 283: 1491014914. DOI: 10.1074/jbc.C800074200.

248. Köhler G, Milstein C. (1975) Continuous cultures of fused cells secreting antibody of predefined specificity. Nature; 256: 495-497.

249. Kucia M, Ratajczak MZ. (2006) Stem cells as a two-edged sword-from regeneration to tumor formation. J Physiol Pharmacol.; 57: 5-16.

250. Kudrin, A. (2013) "Cancer Immunotherapy: Paradigms, Practice and Promise.” Human Vaccines \& Immunotherapeutics 9:1553-1554., DOI:10.4161/ hv. 24222 . 
251. Kundu N. et al., (2014) Prostaglandin E receptor EP4 is a therapeutic target in breast cancer cells with stem-like properties. Breast Cancer Res Treat 143: 19-31. DOI: 10.1007/s10549-013-2779-4.

252. Kutzler, M. A. \& Weiner, D. B. (2008) DNA vaccines: ready for prime time? Nature Reviews Genetics 9: 776-788. DOI: 10.1038/nrg2432.

253. Laderoute KR. et al. (2006) 5'-AMP-activated protein kinase (AMPK) is induced by low-oxygen and glucose deprivation conditions found in solid tumor micro environments. Mol Cell Biol. 26: 5336- 47. DOI: 10.1128/ MCB.00166-06

254. Ladurner P, Rieger R, Baguna J. (2000) Spatial distribution and differentiation potential of stem cells in hatchlings and adults in the marine Platyhelminth macrostomum sp.: a bromodeoxyuridine analysis. Dev Biol 226: 231-241. DOI: 10.1006/dbio.2000.9867

255. Lamouille S, Xu J, Derynck R. (2014) Molecular mechanisms of epithelial mesenchymal transition. Nat Rev Mol Cell Biol 5: 178-96. DOI: 10.1038/ nrm3758.

256. Lapidot T, Sirard C, Vormoor J, et al. (1994) A cell initiating human acute myeloid leukaemia after transplantation into SCID mice. Nature 367: 645648. DOI:10.1038/367645a0

257. Lazebnik, Y. (2010) What are the hallmarks of cancer? Nature Reviews Cancer 10: 232-233. DOI: 10.1038/nrc2827.

258. LeBleu VS. (2015) Imaging the Tumor Microenvironment. Cancer journal 21: 174-8. DOI: 10.1097/PPO.0000000000000118.

259. Ledford, H. (2011) Cancer theory faces doubts. Nature 472: 273-273. DOI:10.1038/472273a

260. Lee $\mathrm{CH}$, et al., (2013) Inhaled corticosteroid use and risks of lung cancer and laryngeal cancer. Respir Med 107: 1222-33. DOI: 10.1016/j. rmed.2012.12.002.

261. Leggett, S. E., Khoo, A. S. \& Wong, I. Y. (2017) Multicellular tumor invasion and plasticity in biomimetic materials. Biomaterials Science 5: 14601479. DOI: 10.1039/c7bm00272f.

262. Levine, B, Mizushima, N, Virgin, H.W. (2011) Autophagy in immunity and inflammation, Nature 469: 323-335. DOI: 10.1038/nature09782.

263. Li F et al., (2007) Beyond tumorigenesis: cancer stem cells in metastasis. Cell Res. 17: 3-14. DOI:10.1038/sj.cr.7310118

264. Li W. et al. (2017) Unraveling the roles of CD44/CD24 and ALDH1 as cancer stem cell markers in tumorigenesis and metastasis. Sci Rep. 7: 13856. DOI: 10.1038/s41598-017-14364-2.

265. Li, F., et al., (2016) The selective estrogen receptor modulators in breast cancer prevention. Cancer Chemotherapy and Pharmacology 77: 895-903. DOI: $10.1007 / \mathrm{s} 00280-016-2959-0$. 
266. Liao, Q. et al. (2013) Prohibitin is an important biomarker for nasopharyngeal carcinoma progression and prognosis. European Journal of Cancer Prevention 22: 68-76. DOI.org/10.1097/CEJ.0b013e328354d351.

267. Lim J, Thiery JP. (2012) Epithelial-mesenchymal transitions: insights from development. Development 139: 3471-86. DOI: 10.1242/dev.071209.

268. Liu SP, Fu RH, Huang SJ, et al. (2013) Stem cell applications in regenerative medicine for neurological disorders. Cell Transpl 22: 631-637. DOI: $10.3727 / 096368912$ X655145.

269. Liu, Y. et al. (2015) Transition of Mesothelial Cell to Fibroblast in Peritoneal Dialysis: EMT, Stem Cell or Bystander? Peritoneal Dialysis International 35: 14-25. DOI: 10.3747/pdi.2014.00188.

270. Liu, Y. et al. (2018) Abscopal effect of radiotherapy combined with immune checkpoint inhibitors. Journal of Hematology \& Oncology 11: 104.

271. Lucena SR. et al. (2015) Combined Treatments with Photodynamic Therapy for Non-Melanoma Skin Cancer. Int J Mol Sci 16: 25912-33. DOI: 10.3390/ijms161025912.

272. Luo, T.-Y. et al. (2014) 188Re-HYNIC-trastuzumab enhances the effect of apoptosis induced by trastuzumab in HER2-overexpressing breast cancer cells. Annals of Nuclear Medicine 29: 52-62. DOI: 10.1007/s12149-0140908-8.

273. Lyons SD, Law KSK. (2013) Laparoscopic vessel sealing technologies. J Minim Invasive Gynecol 20: 301-307. DOI: 10.1016/j.jmig.2013.02.012.

274. Ma CX, Ellis MJ.(2013) The Cancer Genome Atlas: clinical applications for breast cancer. Oncology $12: 1263-9,1274-9$. PMID:24624545

275. Madorsky Rowdo FP. et al. (2015) Immunotherapy in Cancer: A Combat between Tumors and the Immune System; You Win Some, You Lose Some. Front Immunol 6: 127. DOI: 10.3389/fimmu.2015.00127.

276. Magee, J. A., Piskounova, E. \& Morrison, S.J. (2012) Cancer Stem Cells: Impact, Heterogeneity, and Uncertainty. Cancer Cell 21: 283-296. DOI: 10.1016/j.ccr.2012.03.003.

277. Malandrino, A., Kamm, R. D. \& Moeendarbary, E. (2017) In Vitro Modeling of Mechanics in Cancer Metastasis. ACS Biomaterials Science \& Engineering 4, 294-301. DOI: 10.1021/acsbiomaterials.7b00041.

278. Mani SA, Guo W, Liao MJ, Eaton EN, Ayyanan A, Zhou AY, et al. (2008) The epithelial-mesenchymal transition generates cells with properties of stem cells. Cell. 133: 704-15. DOI: 10.1016/j.cell.2008.03.027.

279. Mani, S. A. et al. (2008) The Epithelial-Mesenchymal Transition Generates Cells with Properties of Stem Cells. Cell 133: 704-715. DOI:10.1016/j. cell.2008.03.027

280. Mantovani A, et al., (2008) Cancer-related inflammation. Nature 454: 436444. DOI: $10.1038 /$ nature07205. 
281. Marotta, L. L. et al. (2011) The JAK2/STAT3 signaling pathway is required for growth of CD44 CD24- stem cell-like breast cancer cells in human tumors. Journal of Clinical Investigation 121: 2723-2735.DOI: 10.1172/ JCI44745.

282. Martinez-Outschoorn UE, et al., (2017) Cancer metabolism: a therapeutic perspective. Nat Rev Clin Oncol 14: 11-31. DOI: 10.1038/nrclinonc.2016.60.

283. Masui K., Mischel P.S., Reifenberger G. (2016) Molecular classification of gliomas. Handb. Clin. Neurol 134: 97-120. DOI: 10.1016/B978-0-12802997-8.00006-2.

284. McGranahan N, Swanton C. (2015) Biological and therapeutic impact of intratumor heterogeneity in cancer evolution. Cancer Cell 27: 15-26. DOI: 10.1016/j.ccell.2014.12.001.

285. McPartlin A. et al. (2014) Successful delivery of chemotherapy to treat small-cell prostate cancer in a patient undergoing haemodialysis. Clin Kidney J 7: 593-4. DOI: 10.1093/ckj/sfu097

286. Mehmet Ali KISAÇAM Penbe Sema TEMIZER OZAN, (2017) Metabolic Requirements and Dependence of Cancer Cells F.Ü.Sağ.Bil.Vet.Derg. 31: 67-72.

287. Melief, C. J. (2008) Cancer Immunotherapy by Dendritic Cells. Immunity 29, 372-383 DOI: 10.1016/j.immuni.2008.08.004.

288. Mercado-Pimentel, M.E., and Runyan, R.B. (2007) Multiple transforming growth factor-beta isoforms and receptors function during epithelial-mesenchymal cell transformation in the embryonic heart. Cells Tissues Organs 185:146-156. DOI:10.1159/000101315

289. Mian M. et al. (2016) Bortezomib, Thalidomide and Lenalidomide: Have They Really Changed the Outcome of Multiple Myeloma? Anticancer Res 36: 1059-65.

290. Michalska, M. et al., (2016) In vitro and in vivo effects of a recombinant anti-PSMA immunotoxin in combination with docetaxel against prostate cancer. Oncotarget 7(16): 22531-22542. DOI: 10.18632/oncotarget.8001.

291. Michnick SW, Sidhu SS (2008) Submitting antibodies to binding arbitration. Nat Chem 4: 326-329.

292. Miller M M., Kearney N. (2001) Oral care.for patients with cancer: A review of the Literature, Cancer Nursing, 24: 241-254. DOI: 10.1097/00002820200108000-00001.

293. Mitsiades, N., Mitsiades, C.S. Richardson, P.G. (2003) The proteasome inhibitor PS- 341 potentiates sensitivity of multiple myeloma cells to conventional chemotherapeutic myeloma after one prior therapy. Clin. Cancer Res. 12: 2955-2960. DOI: 10.1182/blood-2002-06-1768

294. Mittal K, Ebos J, Rini B. (2014) Angiogenesis and the tumor microenvironment: vascular endothelial growth factor and beyond. Semin Oncol 41: 235-51. DOI: 10.1053/j.seminoncol.2014.02.007. 
295. Monahan-Earley, R., Dvorak, A. M. \& Aird, W. C. (2013) Evolutionary origins of the blood vascular system and endothelium. Journal of Thrombosis and Haemostasis 11: 46-66. DOI: 10.1111/jth.12253.

296. Morandi, A., Taddei, M. L., Chiarugi, P. \& Giannoni, E. (2017) Targeting the Metabolic Reprogramming That Controls Epithelial-to-Mesenchymal Transition in Aggressive Tumors. Frontiers in Oncology 7:40. DOI: 10.3389/fonc.2017.00040.

297. Moreno-Bueno G, et al. (2009) The morphological and molecular features of the epithelial-to-mesenchymal transition. Nat Protoc $4: 1591-613$. DOI:10.1038/ nprot.2009.

298. Morikawa S et al. (2002) Abnormalities in pericytes on blood vessels and endothelial sprouts in tumors. Am. J. Pathol 160: 985-1000. DOI: 10.1016/ S0002-9440(10)64920-6

299. Moriyama T. et al, (2010) Enhanced cell migration and invasion of CD133+ pancreatic cancer cells cocultured with pancreatic stromal cells. Cancer. 116: 3357-68. DOI: 10.1002/cncr.25121.

300. Moyer, T. J., Zmolek, A. C. \& Irvine, D. J. (2016) Beyond antigens and adjuvants: formulating future vaccines. Journal of Clinical Investigation 126: 799-808. DOI: 10.1172/JCI81083.

301. Möller, T. R., et al. (2003) Radiotherapy and Cancer Care in Sweden. Acta Oncologica 42: 366-375. DOI: 10.1080 / 02841860310010817.

302. Mueller MM, Fusenig NE. (2004) Friends or foes - bipolar effects of the tumour stroma in cancer. Nat Rev Cancer 4: 839-49. DOI: 10.1038/nrc1477

303. Muhammet Yusuf Tepebaşı Nilüfer Şahin Calapoğlu, (2016) Hipoksi ile indüklenen faktör-1 alfa (HIF-1 $\alpha$ ) C111A gen polimorfizmi ile hemoglobin konsantrasyonu arasındaki ilişkinin araştırılması SDÜ Tıp Fak Dergisi 23: 53-59.

304. Nawshad, A., et al., (2005) Transforming Growth Factor- $\beta$ Signaling during Epithelial-Mesenchymal Transformation: Implications for Embryogenesis and Tumor Metastasis. Cells Tissues Organs 179:11-23. DOI:10.1159/000084505

305. Neviani, P. \& Fabbri, M. (2015) Exosomic microRNAs in the Tumor Microenvironment. Frontiers in Medicine 2: 47. DOI: 10.3389/ fmed.2015.00047.

306. Newburger, Peter E., and David C. Dale. (2013) "Evaluation and Management of Patients With Isolated Neutropenia." Seminars in Hematology, 50:198-206 DOI:10.1053/j.seminhematol.2013.06.010.

307. Nguyen, D. X., Bos, P. D. \& Massagué, J. (2009) Metastasis: from dissemination to organ-specific colonization. Nature Reviews Cancer 9: 274-284. DOI: $10.1038 / \mathrm{nrc} 2622$.

308. Nieto MA et al . (2016) EMT: 2016. Cell 166 21-45. DOI: 10.1016/j. cell.2016.06.028. 
309. Nieto MA. (2011) The ins and outs of the epithelial to mesenchymal transition in health and disease. Annu. Rev. Cell Dev. Biol. 27: 347-376. DOI: 10.1146/annurev-cellbio-092910-154036.

310. Nieto MA. (2013) Epithelial plasticity: a common theme in embryonic and cancer cells. Science 342: 1234850. DOI: 10.1126/science.1234850.

311. Nieto MA. et al. (2016) Emt: 2016. Cell 166: 21-45. DOI: 10.1016/j. cell.2016.06.028.

312. Nilsson G.M.et al. (2014) Baeckstrom Loss of E-cadherin expression is not a prerequisite for c-erbB2-induced epithelial-mesenchymal transition Int. J. Oncol 45: 82-94. DOI: 10.3892/ijo.2014.2424

313. Nowak M.A, Michor F, Iwasa Y. (2003) The linear process of somatic evolution. PNAS 100: 14966-69. DOI.org/10.1073/pnas.2535419100

314. Nowell PC. (1976) The clonal evolution of tumor cell populations. Science.; 194: 23-8. DOI: 10.1126/science.959840

315. Noy R., Pollard J.W. (2016)Tumor-associated macrophages: from mechanisms to therapy. Immunity 41:49-61. DOI: 10.1016/j.immuni.2014.06.010.

316. Oda, Y. et al. (2012) Prophylactic immunization with Bubble liposomes and ultrasound-treated dendritic cells provided a four-fold decrease in the frequency of melanoma lung metastasis. Journal of Controlled Release 160: 362-366. DOI: 10.1016/j.jconrel.2011.12.003.

317. Odoux C, et al. (2008) A stochastic model for cancer stem cell origin in metastatic colon cancer. Cancer Res 68 : 6932-41. DOI: 10.1158/00085472.CAN-07-5779

318. Oft, M., Heider, K.H. and Beug, H. (1998) TGFbeta signaling is necessary for carcinoma cell invasiveness and metastasis. Curr.Biol 8: 1243-1252.

319. Ogawa M. (1993) Differentiation and proliferation of hematopoietic stem cells. Blood;81: 2844-53.

320. Ohlmann CH. (2015) Chemotherapy of prostate cancer. Urologe A 54: 1461-9. DOI: 10.1007/s00120-015-3911-3.

321. Olsen IH. et al. (2014) Topotecan monotherapy in heavily pretreated patients with progressive advanced stage neuroendocrine carcinomas. J Cancer 5: 628-32. DOI:10.7150/jca.9409.

322. Organista-Nava, J., Gómez-Gómez, Y. \& Gariglio, P. (2011) Embryonic stem cell-specific signature in cervical cancer. Tumor Biology 35: 17271738. DOI: 10.1007/s13277-013-1321-y.

323. Oskarsson T. et al. (2011) Breast cancer cells produce tenascin C as a metastatic niche com-ponent to colonize the lungs. Nat Med 17: 867-74 . DOI: 10.1038/nm.2379.

324. Panková K. (2010) The molecular mechanisms of transition between mesenchymal and amoeboid invasiveness in tumor cells. Cell. Mol. Life Sci 67: 63-71. DOI: 10.1007/s00018-009-0132-1. 
325. Panowski, B. R. (2013) Site-specific antibody drug conjugates for cancer therapy.mAbs, 48(10), 34-45. DOI: 10.4161/mabs.27022. 7

326. Parsons D.W. et al., (2008) An integrated genomic analysis of human glioblastoma multiforme. Science 321: 1807-1812. DOI: 10.1126/science.1164382.

327. Patel, S. \& Goyal, A. (2011) Recent developments in mushrooms as anti-cancer therapeutics: a review. 3 Biotech 2: 1-15. DOI: 10.1007/s13205011-0036-2

328. Paterson AD.et al. (2003) Characterization of E-cadherin endocytosis in isolated MCF-7 and Chinese hamster ovary cells: the initialfate of unbound E-cadherin. J BiolChem 278: 21050-7. DOI:10.1074/jbc.M300082200

329. Patil Y. et al. (2016) Targeting of pegylated liposomal mitomycin-C prodrug to the folate receptor of cancer cells: Intracellular activation and enhanced cytotoxicity. J Control Release 225, 87-95. DOI: 10.1016/j.jconrel.2016.01.039.

330. Pattabiraman DR, Weinberg RA, (2014), Tackling the cancer stem cellswhat challenges do they pose? Nat Rev Drug Discov. 13: 497-512. DOI: $10.1038 / \mathrm{nrd} 4253$.

331. Peinado H, et al. (2012) Melanoma exosomes educate bone marrow progenitor cells toward a pro-metastatic phenotype through MET. Nat Med 18: 883-891. DOI: $10.1038 / \mathrm{nm} .2753$.

332. Peinado H, Lavotshkin S, Lyden D. (2011) The secreted factors responsible for pre-metastatic niche formation: old sayings and new thoughts. Semin Cancer Biol 21: 139-146. DOI: 10.1016/j.semcancer.2011.01.002.

333. Peinado, H. et al. (2017) Pre-metastatic niches: organ-specific homes for metastases. Nature Reviews Cancer 17: 302-317.

334. Peiris-Pagès, M., Martinez-Outschoorn, U. E., Pestell, R. G., Sotgia, F. \& Lisanti, M. P. (2016) Cancer stem cell metabolism. Breast Cancer Research 18: 55. DOI: 10.1186/s13058-016-0712-6

335. Perica, K.,et al., (2015) Adoptive T Cell Immunotherapy For Cancer. Rambam Maimonides Medical Journal, 6(1). DOI: 10.5041/rmmj.10179

336. Perry A., Wesseling P. (2016) Histologic classification of gliomas. Handb. Clin. Neurol 134: 71-95. DOI.org/10.1016/B978-0-12-802997-8.00005-0

337. Pessina A, Gribaldo L. (2006) The key role of adult stem cells: therapeutic perspectives. Curr Med Res Opin.22:2287-2300. DOI: 10.1185/030079906X148517

338. Pittayapruek, P., et al., (2016). Role of Matrix Metalloproteinases in Photoaging and Photocarcinogenesis. International Journal of Molecular Sciences, 17(6), 868. DOI:10.3390/ijms17060868

339. Podlaha O, Riester M, De S, (2012) Michor F. Evolution of the cancer genome. Trends Genet. 28: 155-63. DOI: 10.1016/j.tig.2012.01.003. 
340. Podsypanina K, et al. (2008) Seeding and propagation of untransformed mouse mammary cells in the lung. Science 321: 1841-1844. DOI: $10.1126 /$ science.1161621.

341. Polyak K, Weinberg RA. (2009) Transitions between epithelial and mesenchymal states: acquisition of malignant and stem cell traits. Nat Rev Cancer 9: 265-73. DOI: 10.1038/nrc2620.

342. Porta, C. A. M. L., Zapperi, S. \& Sethna, J. P. (2012) Senescent Cells in Growing Tumors: Population Dynamics and Cancer Stem Cells. PLoS Computational Biology ; 8(1): e1002316. DOI: 10.1371/journal.pcbi.1002316

343. Pravin Bhattarai, Sadaf Hameed, and Zhifei Dai, (2018) Recent advances in anti-angiogenic nanomedicines for cancer therapy, Nanoscale, DOI: 10.1039/ c7nr09612g.

344. Psaila B, Lyden D. (2009) The metastatic niche: Adapting the foreign soil. Nat Rev Cancer 9: 285-293. DOI: 10.1038/nrc2621.

345. Quail DF, Joyce JA. (2013) Microenvironmental regulation of tumor progression and metastasis. Nat Med 19: 1423-1437. DOI: 10.1038/nm.3394

346. R. Kalluri, R.A. Weinberg (2009) The basics of epithelial-mesenchymal transitionJ. Clin. Invest 119: 1420-1428. DOI: 10.1172/JCI39104.

347. Rael, E. et al. (2016) Treatment with rituximab and brentuximab vedotin in a patient of common variable immune deficiency-associated classic Hodgkin lymphoma. Biomarker Research 4: 7 DOI: 10.1186/s40364-016-0061-8

348. Raffaele A, et al. (2010) Panitumumab: a new frontier of target therapy for the treatment of metastatic colorectal cancer. Expert Review of Anticancer Therapy; 10: 499-505.

349. Raposo, T., et al., (2015) Inflammation and cancer: Till death tears them apart. The Veterinary Journal 205: 161-174. DOI: 10.1016/j.tvjl.2015.04.015.

350. Reddy P. et al. (2009) GVHD: a continuing barrier to the safety of allogeneic transplantation. Biol Blood Marrow Transplant 15: 162-168. DOI: $10.1016 /$ j.bbmt.2008.10.014

351. Reis ES. et al. (2017) Complement in cancer: untangling an intricate relationship. Nat Rev Immunol 18: 5-18. DOI: 10.1038/nri.2017.97.

352. Reynolds BA. Weiss S. (1996) Clonal and population analyses demonstrate that an EGF-responsive mammalian embryonic CNS precursor is a stem cell. Dev Biol. 175: 1-13. DOI: 10.1006/dbio.1996.0090

353. Ribatti D. (2017) Epithelial-mesenchymal transition in morphogenesis, cancer progression and angiogenesis. Exp Cell Res. 353: 1-5. DOI: 10.1016/j.yexcr.2017.02.041.

354. Rijal, G. \& Li, W. (2018) Native-mimicking in vitro microenvironment: an elusive and seductive future for tumor modeling and tissue engineering. Journal of Biological Engineering 12:20. DOI: 10.1186/s13036-0180114-7. 
355. Rivankar S. (2014) An overview of doxorubicin formulations in cancer therapy. J Cancer Res Ther 10: 853-858 . DOI: 10.4103/0973-1482.139267.

356. Rodriguez YI et al. (2016) Sphingosine-1 Phosphate: A New Modulator of Immune Plasticity in the Tumor Microenvironment. Frontiers in oncology 6 : 218. DOI: $10.3389 /$ fonc. 2016.00218

357. Rogers CD, Jayasena CS, Nie S, Bronner ME. (2012) Neural crest specification: tissues, signals, and transcription factors. Wiley Interdiscip Rev Dev Biol. 1: 52-68. DOI: 10.1002/wdev.8.

358. Roland, K. B., et al. (2016) Changes in Knowledge and Beliefs About Human Papillomavirus and Cervical Cancer Screening Intervals in Low-Income Women After an Educational Intervention. Journal of Primary Care \& Community Health 7: 88-95. DOI: 10.1177/2150131915624869.

359. Rosenberg, S. A. (2014) Entering the mainstream of cancer treatment. Nature Reviews Clinical Oncology 11: 630-632. DOI: 10.1038/nrclinonc.2014.174.

360. Ross, G. (1999) Induction of cell death by radiotherapy. Endocrine Related Cancer 6: 41-44 . DOI: 10.1677 / erc.0.0060041.

361. Roth, A.D, Maibach, R., Fazio, N., (2004) “5Fluorouracilas protracted continuous intravenous infusion can be added to full-dose docetaxel (Taxotere)-cisplatin in advanced gastric carcinoma: a phase I-II trial”. Ann Oncol 15: 759-764. DOI: 10.1093/annonc/mdh187.

362. Royce, M. E. \& Osman, D. (2015) Everolimus in the Treatment of Metastatic Breast Cancer. Breast Cancer: Basic and Clinical Research 9: 73-79. DOI: 10.4137/BCBCR.S29268

363. Rubin DC, Shaker A, Levin MS. (2012) Chronic intestinal inflammation: inflammatory bowel disease and colitis-associated colon cancer. Front Immunol. 3:107 . DOI: 10.3389/fimmu.2012.00107.

364. Ruck, T. et al. (2016) ALAIN01-Alemtuzumab in autoimmune inflammatory neurodegeneration: mechanisms of action and neuroprotective potential. BMC Neurology 16: 16414-16439 DOI: 10.1186/s12883-016-0556-9.

365. Ruella M, Kalos M. (2014) Adoptive immunotherapy for cancer. Immunol Rev. 257:14-38. DOI: 10.1111/imr.12136.

366. Ruoslahti E. (2002) Specialization of tumour vasculature. Nat. Rev. Cancer 2: 83-90. DOI: $10.1038 / \mathrm{nrc} 724$

367. Ruscetti, M.,et al., (2015) Tracking and Functional Characterization of Epithelial-Mesenchymal Transition and Mesenchymal Tumor Cells during Prostate Cancer Metastasis. Cancer Research 75. 2749-2759. DOI: 10.1158/0008-5472.CAN-14-3476.

368. Ruvolo, P. P. (2019) Role of protein phosphatases in the cancer microenvironment. Biochimica et Biophysica Acta (BBA)-Molecular Cell Research 1866: 144-152. DOI: 10.1016/j.bbamcr.2018.07.006. 
369. S. Loffek, O. Schilling, C.W. (2011), Franzke Biological role of matrix metalloproteinases: a critical balance Eur. Respir. J., 38 (1) pp. 191-208

370. S.Mert Selimoğlu, et al. (2016), Monoklonal Antikor Teknolojisinin Dünü, Bugünü ve Geleceği, Journal of Health Sciences of Kocaeli University,January (Vol.2, No.1, pp. 6-14.

371. Saitoh, M. (2015) Epithelial-mesenchymal transition is regulated at post-transcriptional levels by transforming growth factor- $\beta$ signaling during tumor progression. Cancer Science 106: 481-488. DOI: 10.1111/cas.12630.

372. Sakai M. et al. (2015) The GnRH Antagonist Degarelix Directly Inhibits Benign Prostate Hyperplasia Cell Growth. Horm Metab Res 47: 925-31. DOI: $10.1055 /$ s-0035-1555899.

373. Salama JK et al. (2016) Positive Interaction between Prophylactic Cranial Irradiation and Maintenance Sunitinib for Untreated Extensive-Stage Small Cell Lung Cancer Patients After Standard Chemotherapy: A Secondary Analysis of CALGB 30504 (ALLIANCE). J Thorac Oncol 11: 361. DOI: 10.1016/j.jtho.2015.11.001.

374. Salamon S. et al. (2017) Glucose metabolism in cancer and ischemia: Possible therapeutic consequences of the warburg effect. Nutr Cancer 69: 177183. DOI: 10.1080/01635581.2017.1263751.

375. Samanc1 N, Balc1 N. (2006) Kortikosteroidler ve klinikte kullanımı. T klin tip bilimleri 21: 131-40.

376. Saunders LR, McClay DR. (2014) Sub-circuits of a gene regulatory network control a developmental epithelial-mesenchymal transition. Development 141: 1503-13. DOI: 10.1242/dev.101436.

377. Schatton T, Frank NY, Frank MH. (2009) Identification and targeting of cancer stem cells. Bioessays 31: 1038-1049. DOI: 10.1002/bies.200900058.

378. Schatton T, Murphy GF, Frank NY, et al. (2008) Identification of cells initiating human melanomas. Nature 451: 345-U311. DOI: 10.1038/nature06489.

379. Schreibelt, G. et al. (2016) Effective clinical responses in metastatic melanoma patients after vaccination with primary myeloid dendritic cells. Clinical cancer research 22:, 2155-2166. DOI: 10.1158/1078-0432.CCR-15-2205.

380. Sehl ME et al. (2015) Modeling of cancer stem cell state transitions predicts therapeutic response. PLoS One. 10: e0135797. DOI.org/10.1371/journal. pone. 0135797

381. Seiki M, Yana I. (2003) Roles of pericellular proteolysis by membrane type1 matrix metalloproteinase in cancer invasion and angiogenesis. Cancer Sci 94: 569-74. DOI:10.1111/j.1349-7006.2003.tb01484.x

382. Serhan CN. (2014) Pro-resolving lipid mediators are leads for resolution physiology. Nature 510: 92-101. DOI: 10.1038/nature13479.

383. Sethi N, Kang Y. (2011) Unravelling the complexity of metastasis-molecular understanding and targeted therapies. Nat Rev Cancer 11: 735-748. DOI: $10.1038 / \mathrm{nrc} 3125$. 
384. Shackleton M. et al. (2009) Heterogeneity in cancer: cancer stem cells versus clonal evolution. Cell , 138: 822-829. DOI: 10.1016/j.cell.2009.08.017.

385. Shah, A. \& Mangaonkar, A. (2015) Idelalisib: a novel PI3K $\delta$ inhibitor for chronic lymphocytic leukemia. Annals of Pharmacotherapy, 49: 11621170. DOI: $10.1177 / 1060028015594813$.

386. Shao, D. et al. (2015) Noninvasive theranostic imaging of HSV-TK/GCV suicide gene therapy in liver cancer by folate-targeted quantum dot-based liposomes. Biomaterials Science 3: 833-841. DOI: 10.1039/c5bm00077g.

387. Shapiro SD, Senior RM. (1999) Matrix metalloproteinases. Matrix degradation and more. Am J Respir Cell Mol Biol.;20:1100-1102. DOI: 10.1165/ ajrcmb.20.6.f151.

388. Sharma, A., Khatun, Z. \& Shiras, A. (2016) Tumor exosomes: cellular postmen of cancer diagnosis and personalized therapy. Nanomedicine 11: 421437. DOI: $10.2217 / \mathrm{nnm} .15 .210$.

389. Shen, A., et al., (2015) p53 gene therapy-based transarterial chemoembolization for unresectable hepatocellular carcinoma: A prospective cohort study. Journal of Gastroenterology and Hepatology 30: 1651-1656. DOI: 10.1111/jgh.13009.

390. Shi Q, et al. (2001) Regulation of vascular endothelial growth factor expression by acidosis in human cancer cells. Oncogene 20: 3751-6. DOI: $10.1038 /$ sj.onc. 1204500

391. Shimasaki N,et al., (2016) Expanded and armed natural killer cells for cancer treatment. Cytotherapy.;18:1422-1434. DOI: 10.1016/j.jcyt.2016.06.013.

392. Shipitsin M. et al. (2007) Molecular definitionof breast tumor heterogeneity. Cancer Cell. 11: 259-73. DOI:10.1016/j.ccr.2007.01.013

393. Simeon Cua, et al. (2018), Targeting of embryonic annexin A2 expressed on ovarian and breast cancer by the novel monoclonal antibody 2448 , Oncotarget, Vol. 9, (No. 17), pp: 13206-13221. DOI: 10.18632/oncotarget.24152

394. Singh SK, et al . (2004) Identification of human brain tumour initiating cells. Nature; 432: 396-401. DOI:10.1038/nature03128

395. Sinobiological (2018) Role of Cytokines in cancer son erişim: 22.08.2018

396. Slamon DJ, Leyland-Jones B, Shak S, et al. (2001) Use of chemotherapy plus a monoclonal antibody against HER2 for metastatic breast cancer that overexpresses HER2. N Engl J Med; 344: 783-792.

397. Snyder, V., Reed-Newman, T. C., Arnold, L., Thomas, S. M. \& Anant, S. (2018) Cancer Stem Cell Metabolism and Potential Therapeutic Targets. Frontiers in Oncology ; 8: 203. DOI: 10.3389/fonc.2018.00203.

398. Song, Y. et al. (2016) Epstein-Barr virus encoded miR-BART11 promotes inflammation-induced carcinogenesis by targeting FOXP1. Oncotarget 7:36783-36799. DOI.org/10.18632/ oncotarget.9170.

399. Soung YH. et al. (2016) Emerging roles of exosomes incancer invasion and metastasis. BMB reports 49: 18-25. DOI: 10.5483/BMBRep.2016.49.1.239. 
400. Steeg PS. Tumor metastasis: (2006) Mechanistic insights and clinical challenges. Nat Med. 12(8):895-904. DOI.org/10.1038/nm1469

401. Steinhäuser, C., Seifert, G. \& Joachim W. Deitmer. (2013) Physiology of Astrocytes: Ion Channels and Ion Transporters. Oxford Medicine Online DOI:10.1093/med/9780199794591.003.0016

402. Stenken, J. A. \& Poschenrieder, A. J. (2015) Bioanalytical chemistry of cytokines - A review. Analytica Chimica Acta 853: 95-115. DOI: 10.1016/j. aca.2014.10.009.

403. Stewart, E. A. (2015) Uterine Fibroids. New England Journal of Medicine 372: 1646-1655. DOI: 10.1016/S0140-6736(00)03622-9

404. Stifter, K., et al., (2016) Exploring the induction of preproinsulin-specific Foxp3 CD4 Treg cells that inhibit CD8 T cell-mediated autoimmune diabetes by DNA vaccination. Scientific Reports 6: 29419. DOI: 10.1038/ srep29419.

405. Strutz, F. et al. (2001) TGF- $\beta 1$ induces proliferation in human renal fibroblasts via induction of basic fibroblast growth factor (FGF-2). Kidney International 59: 579-592. DOI:10.1046/j.1523-1755.2001.059002579.x

406. Sullivan R. et al. (2015) Delivering safe and affordable cancer surgery to all. The lancet oncology commission on global cancer surgery. Lancet Oncol. 16: 1193-1224. DOI: 10.1016/S1470-2045(15)00223-5

407. Sun Y. (2016) Tumor microenvironment and cancer therapy resistance. Cancer Lett. 380: 205-15. DOI: 10.1016/j. canlet.2015.07.044.

408. Sun, L., et al., (2015) CCL21/CCR7 up-regulate vascular endothelial growth factor-D expression via ERK pathway in human non-small cell lung cancer cells. International journal of clinical and experimental pathology 8: 15729. PMID: 26884842

409. Swanton C. (2012) Intratumor heterogeneity: evolution through space and time. Cancer Res. 72: 4875-82. DOI: 10.1158/0008-5472.CAN-12-2217.

410. Şakalar, Ç., İzgi, K., Canatan, H. (2013) Kanser İmmün Terapi ve Monoklonal Antikorlar. F. Ü. Sağ. Bil. Tip Derg., 27: 105-110.

411. Tabassum DP, Polyak K. (2015) Tumorigenesis: It takes a village. Nat. Rev. Cancer 15: 473-83. DOI: 10.1038/nrc3971.

412. Takahashi K, Yamanaka S. (2013) Induced pluripotent stem cells in medicine and biology. Development. 140: 2457-61. DOI: 10.1242/dev.092551.

413. Takeuchi A. et al. (2015) Renal cancer treatment with recipient lymphocyte infusion enhanced the antitumor effect of nonmyeloablative allogeneic stem cell transplantation. Transpl Immunol. 32: 131-9. DOI: 10.1016/j. trim.2014.12.001.

414. Talmadge JE, Fidler IJ. (2010) AACR centennial series: the biology of cancer metastasis: historical perspective. Cancer Res 70: 5649-69. DOI: 10.1158/0008-5472.CAN-10-1040. 
415. Tan C, et al. (2018) Cytokine-mediated therapeutic resistance in breast cancer. Cytokine.;108:151-159. DOI: 10.1016/j.cyto.2018.03.020.

416. Tan, J.-J. et al. (2011) Isolation and Expansion of Cardiosphere-Derived Stem Cells. Current Protocols in Stem Cell Biology 16: 2C.3.1-2C.3.12 DOI: $10.1002 / 9780470151808 . s c 02 c 03 s 16$

417. Tang C, Ang BT, Pervaiz S. (2007) Cancer stem cell: target for anticancer therapy. FASEB J 21: 3777-3785. DOI:10.1096/fj.07-8560rev

418. Tang, Y. et al., (2017) Co-expression of AFAP1-AS1 and PD-1 predicts poor prognosis in nasopharyngeal carcinoma. Oncotarget 8: 39001-39011. DOI.org/10.18632/oncotarget.16545.

419. Tanyi, J. L., et al., (2018). Personalized cancer vaccine effectively mobilizes antitumor T cell immunity in ovarian cancer. Science Translational Medicine, 10(436). DOI: 10.1126/scitranslmed.aao5931

420. Tao L., Li Z., Lin L., et al.( 2015) MMP1, 2, 3, 7, and 9 gene polymorphisms and urinary cancer risk: a meta-analysis. Genetic Testing and Molecular Biomarkers. 19(10):548-555. DOI: 10.1089/gtmb.2015.0123.

421. Tarin, D. et al. (2005) The Fallacy of Epithelial Mesenchymal Transition in Neoplasia. Cancer Research 65: 5996-6001. DOI:10.1158/0008- 5472. CAN-05-0699

422. Taylor DD, Gercel-Taylor C. (2011) Exosomes/microvesicles: mediators of cancer-associated immunosuppressive microenvironments. Semin Immunopathol 33: 441- 54. DOI: 10.1007/s00281-010-0234-8.

423. Tel, J. et al. (2013) Natural Human Plasmacytoid Dendritic Cells Induce Antigen-Specific T-Cell Responses in Melanoma Patients. Cancer Research 73: 1063-1075. DOI: 10.1158/0008-5472.CAN-12-2583.

424. the tumor microenvironment. Cell 141(1):52-67.

425. Thiery JP, Acloque H, Huang RY,Nieto MA. (2009) Epithelial-mesenchymal transionsin development and disease. Cell 139: 871-90. DOI: 10.1016/j.cell.2009.11.007.

426. Thiery JP, Sleeman JP. (2006) Complex networks orchestrate epithelial-mesenchymal transitions. Nat Rev Mol Cell Biol 7: 131-142. DOI: $10.1038 / \mathrm{nrm} 1835$

427. Thiery JP.et al. (2009) Epithelial-mesenchymal transitions in development and disease. Cell 139: 871-90. DOI: 10.1016/j.cell.2009.11.007.

428. Thiery, J. P. (2002) Epithelial-mesenchymal transitions in tumour progression. Nature Reviews Cancer 2: 442-454. DOI: 10.1038/nrc822

429. Thirkettlev S. (2013) Investigation of the functions of Matrix Metalloproteinase-8 (MMP-8) in Mammary Carcinoma Cells , JOURNAL OF BIOLOGICAL CHEMISTRY , 288; 23

430. Thompson, P. A., Kantarjian, H. M. \& Cortes, J. E. (2015) Diagnosis and Treatment of Chronic Myeloid Leukemia in 2015. Mayo Clinic Proceedings 90: 1440-1454. DOI: 10.1016/j.mayocp.2015.08.010. 
431. Tokito, A., \& Jougasaki, M. (2016). Matrix Metalloproteinases in Non-Neoplastic Disorders. International Journal of Molecular Sciences, 17(7), 1178. DOI: $10.3390 /$ ijms 17071178

432. Torre, L. A. et al. (2015) Global cancer statistics, 2012. CA: A Cancer Journal for Clinicians ; 65: 87-108. DOI: 10.3322/caac.21262.

433. Torre, L. A., Islami, F., Siegel, R. L., Ward, E. M. \& Jemal, A. (2017) Global Cancer in Women: Burden and Trends. Cancer Epidemiology Biomarkers \& Prevention 26: 444-457. DOI: 10.1158/1055-9965.EPI-16-0858.

434. Tsai YP, et al. (2014) TET1 regulates hypoxia-induced epithelial-mesenchymal transition by acting as a co-activator. Genome Biol 15: 513. DOI: 10.1186/s13059-014-0513-0.

435. Tu LC, Foltz G, Lin E, Hood L, Tian Q. (2009) Targeting stem cells-clinical implications for cancer therapy. Curr Stem Cell Res Ther. 4: 147-53. DOI: $10.2174 / 157488809788167373$

436. Tu, J., et al., (2018) Ultrasound-mediated microbubble destruction: a new method in cancer immunotherapy. OncoTargets and Therapy 11: 57635775. DOI: 10.2147/OTT.S171019

437. Urashima, Tetsuro, et al. (2006) "Induction of Apoptosis in Human Tumor Cells after Exposure to Auger Electrons: Comparison with $\gamma$-Ray Exposure." Nuclear Medicine and Biology, 33: 1055-1063., DOI:10.1016/j.nucmedbio.2006.09.002.

438. Vadrevu SK. et al. (2014) Complement c5a receptor facilitates cancer metastasis by altering T-cell responses in the metastatic niche. Cancer Res 74: 3454-65. DOI: 10.1158/0008-5472.CAN-14-0157.

439. Valastyan S, Weinberg RA. (2011) Tumor metastasis: molecular insights and evolving paradigms. Cell 147: 275-92. DOI: 10.1016/j.cell.2011.09.024.

440. Valent P, et al. (2012) Cancer stem cell definitions and terminology: the devil is in the details. Nat Rev Cancer. 12:767-775. DOI: $10.1038 / \mathrm{nrc3368}$.

441. Valent, P. et al., (2012) Cancer stem cell definitions and terminology: the devil is in the details. Nature Reviews Cancer 12: 767-775. DOI: $10.1038 / \mathrm{nrc} 3368$.

442. Vander Heiden MG, et al., (2009) Understanding the Warburg effect: the metabolic requirements of cell proliferation. Science 324: 1029-1033. DOI: 10.1126/science.1160809.

443. Varela G, Gómez-Hernández MT. (2016) Stereotactic ablative radiotherapy for early stage non-small cell lung cancer: a word of caution. Transl Lung Cancer Res 5: 102-5. DOI: 10.3978/j.issn.2218-6751.2015.10.10

444. Varela G, Gómez-Hernández MT. (2016) Stereotactic ablative radiotherapy for early stage non-small cell lung cancer: a word of caution. Transl Lung Cancer Res 5: 102-5. DOI: 10.3978/j.issn.2218-6751.2015.10.10.

445. Vaupel P. (2004) Tumor microenvironmental physiology and its implications for radiation oncology. Semin Radiation Oncol 14: 198-206. DOI: 10.1016/j.semradonc.2004.04.008 
446. Verellen D et al. (2007) Innovations in image-guided radiotherapy. Nat Rev Cancer 7: 949-960. DOI: 10.1038/nrc2288

447. Verellen, D. et al., ( 2008) An overview of volumetric imaging technologies and their quality assurance for IGRT. Acta Oncologica 47: 1271-1278 . DOI: $10.1080 / 02841860802244182$.

448. Verma, S. (2014). Matrix metalloproteinases and gastrointestinal cancers: Impacts of dietary antioxidants. World Journal of Biological Chemistry, 5(3), 355. DOI: 10.4331/wjbc.v5.i3.355

449. Verma, S. et al. (2012) Trastuzumab emtansine for HER2-positive advanced breast cancer. New England Journal of Medicine 367: 1783-1791. DOI: 10.1056/NEJMoa1209124

450. Vicente-Duenas C. et al. (2009) The role of cellular plasticity in cancer development. Curr Med Chem. 16: 3676-3685. DOI: 10.2174/092986709789105019.

451. Visse R, Nagase H. (2003) Matrix metalloproteinases and tissue inhibitors of metalloproteinases: structure, function, and biochemistry. Circ Res;92:827-39

452. Visvader JE, Lindeman GJ (2012) Cancer stem cells: current status and evolving complexities Cell Stem Cell 10: 717-28. DOI: 10.1016/j. stem.2012.05.007.

453. Visvader JE, Lindeman GJ. (2008) Cancer stem cells in solid tumours: accumulating evidence and unresolved questions. Nat RevCancer 8: 755-768. DOI: $10.1038 / \mathrm{nrc} 2499$.

454. Vlashi E, et al. (2009) In vivo imaging, tracking, and targeting of cancer stem cells. J Natl Cancer Inst. 101: 350-359. DOI: 10.1093/jnci/djn509.

455. Vogelstein, B. et al. (2013) Cancer Genome Landscapes. Science 339: 1546-1558. DOI: 10.1126/science.1235122.

456. W.G. Stetler-Stevenson (2008) Tissue inhibitors of metalloproteinases in cell signaling: metalloproteinase-independent biological activities Sci. Signal., 1 (27) p.re6

457. Waclaw B, et al. (2015) A spatial model predicts that dispersal and cell turnover limit intratumour heterogeneity. Nature 525: 261-64. DOI: 10.1038/ nature14971.

458. Wai PY, Kuo PC. (2008) Osteopontin: regulation in tumor metastasis. Cancer Metastasis Rev. 27:103-18 DOI : 10.1007/s10555-007-9104-9

459. Wakamatsu Y, Sakamoto N, Oo HZ, et al. (2012) Expression of cancer stem cell markers ALDH1, CD44 and CD133 in primary tumor and lymph node metastasis of gastric cancer. Pathol Int. 62: 112-119. DOI: 10.1111/j.14401827.2011.02760.x.

460. Waldmann T., (2003) Immunotherapy: Past, Present and Future, Nature Medicine, 9(3), 269-277, DOI: 10.1038/nm0303-269 
461. Wan L. Pantel K. Kang Y. (2013) Tumor metastasis: moving new biological insights into the clinic. Nat. Med 19: 1450-1464. DOI: 10.1038/nm.3391.

462. Wan, L., Pantel, K. \& Kang, Y. (2013) Tumor metastasis: moving new biological insights into the clinic. Nature Medicine 19: 1450-1464. DOI: 10.1038/nm.3391.

463. Wang M, et al. (2017) HIF-1alpha promoted vasculogenic mimicry formation in hepatocellular carcinoma through LOXL2 up-regulation in hypoxic tumor microenvironment. Journal of experimental \& clinical cancer research 36, 60. DOI: 10.1186/s13046-017-0533-1.

464. Wang Z. et al. (2015) Broad targeting of angiogenesis for cancer prevention and therapy. Semin. Cancer Biol 35: S224-S243. DOI: 10.1016/j.semcancer.2015.01.001.

465. Wang, J.-P. et al. (2017) The role of exosomal non-coding RNAs in cancer metastasis. Oncotarget 9:12487-12502. DOI: 10.18632/oncotarget.23552.

466. Wang, M. et al. ( 2017) Role of tumor microenvironment in tumorigenesis. Journal of Cancer 8: 761-773. DOI.org/10.7150/jca.17648.

467. Wang, X., et al., (2015) Muc1 promotes migration and lung metastasis of melanoma cells. American journal of cancer research 5: 2590. PMID:26609470

468. Wculek, S. K. \& Malanchi, I. (2015) Neutrophils support lung colonization of metastasis-initiating breast cancer cells. Nature 528: 413-417 DOI: 10.1038/nature16140.

469. Wei, X. X., Fong, L. \& Small, E. J. (2015) Prostate Cancer Immunotherapy with Sipuleucel-T: Current Standards and Future Directions. Expert Review of Vaccines 14: 1529-1541. DOI: 10.1586/14760584.2015.1099437.

470. Weidenfeld, K. \& Barkan, D. (2018) EMT and Stemness in Tumor Dormancy and Outgrowth: Are They Intertwined Processes? Frontiers in Oncology 8: 381. DOI: 10.3389/fonc.2018.00381

471. Weissman IL. (2000) Stem cells: units of development, units of regeneration, and units in evolution. Cell 100: 157-168 . DOI: 10.1016/S00928674(00)81692-X

472. Welch C, Chen Y, Stallings RL. (2017) MicroRNA-34a functions as a potential tumor suppressor by inducing apoptosis in neuroblastoma cells. Oncogene 26: 5017-5022. DOI : 10.1038/sj.onc.1210293

473. Wen, S. et al. (2016) Efficacy of tamoxifen in combination with docetaxel in patients with advanced non-small-cell lung cancer pretreated with platinum-based chemotherapy. Anti-Cancer Drugs 27: 447-456. DOI: 10.1097/ CAD.0000000000000350.

474. West EE, Kolev M, Kemper C. (2018) Complement and the regulation of T cell responses. Annu Rev Immunol 36: 309-38. DOI: 10.1146/annurev-immunol-042617-053245. 
475. Whiteside TL. (2016) Tumor-derived exosomes and their role in cancer progression. Advances in clinical chemistry 74: 103-41. DOI: 10.1016/ bs.acc.2015.12.005.

476. Wilson WR, Hay MP. (2011) Targeting hypoxia in cancer therapy. Nat Rev Cancer. 11, 393-410 DOI: 10.1038/nrc3064.

477. Wood, D. P. (1997) Evolving Therapies for Prostatic Carcinoma, Encompassing Orchiectomy, Estrogens, and Estramustine. Estrogens, Progestins, and Their Antagonists 161-175. DOI: 10.1007/978-1-4612-4096-9_6

478. Wu, C.-I., Wang, H.-Y., Ling, S. \& Lu, X. (2016) The Ecology and Evolution of Cancer: The Ultra-Microevolutionary Process. Annual Review of Genetics 50: 347-369. DOI:10.1146/annurev-genet-112414-054842

479. Yadav, M. \& Delamarre, L. (2016) Outsourcing the immune response to cancer. Science 352: 1275-1276. DOI: 10.1126/science.aag1547.

480. Yan, Q. et al. (2015) EBV-miR-BART10-3p facilitates epithelial-mesenchymal transition and promotes metastasis of nasopharyngeal carcinoma by targeting BTRC. Oncotarget 6: 41766-41782. DOI. org/10.18632/oncotarget.6155.

481. Yang IA. et al. (2016) Use of inhaled corticosteroids in COPD: improving efficacy. Expert Rev Respir Med 10: 339-50. DOI: 10.1586/17476348.2016.1151789

482. Yang YM, Chang JW. (2008) Bladder cancer initiating cells (BCICs) are among EMA(-)CD44v6(+) subset: novel methods for isolating undetermined cancer stem (initiating) cells. Cancer Invest. 26: 725-733. DOI: 10.1080/07357900801941845.

483. Yang, J. \& Weinberg, R. A. (2008) Epithelial-Mesenchymal Transition: At the Crossroads of Development and Tumor Metastasis. Developmental Cell 14: 818-829 . DOI: 10.1016/j.devcel.2008.05.009.

484. Yang, J. (2016) Of markets and rights: Discourse in the 2008 and 2013 Global Action Plan for the Prevention and Control of Noncommunicable Diseases. Annals of Global Health; 82: 472.

485. Yang, L. et al. (2017) High Expression of LINC01420 indicates an unfavorable prognosis and modulates cell migration and invasion in nasopharyngeal carcinoma. Journal of Cancer 8: 97-103 DOI.org/10.7150/jca.16819.

486. Yang, L. et al. (2013) ALDH1A1 defines invasive cancer stem-like cells and predicts poor prognosis in patients with esophageal squamous cell carcinoma. Modern Pathology 27: 775-783. DOI: 10.1038/modpathol.2013.189.

487. Yang, Y. (2015) Cancer immunotherapy: harnessing the immune system to battle cancer. Journal of Clinical Investigation 125: 3335-3337.DOI: 10.1172/JCI83871

488. Yang, Y. et al. (2013) Correction: LPLUNC1 Inhibits Nasopharyngeal Carcinoma Cell Growth via Down-Regulation of the MAP Kinase and Cyclin D1/E2F Pathways. PLoS ONE 8: 10. DOI.org/10.1371/journal. pone.0062869. 
489. Yao, M., et al., (2016) Cytokine Regulation of Metastasis and Tumorigenicity. Molecular and Cellular Basis of Metastasis: Road to Therapy Advances in Cancer Research. 132:265-367. DOI: 10.1016/bs.acr.2016.05.005.

490. Yates LR, Campbell PJ. (2012) Evolution of the cancer genome. Nat. Rev. Genet. 13: 795-806. DOI: 10.1038/nrg3317.

491. YAZICIOĞLU et al. (2018) Kanserde Hedefe Yönelik Monoklonal Antikor Tedavisi M. Haliç Üniversitesi Fen Bilimleri Dergisi,1: 131-142

492. Yehya A.H., et al. (2017) Broad spectrum targeting of tumor vasculature by medicinal plants: An updated review. J. Herb. Med 9: 1-13. DOI: DOI. org/10.1016/j.hermed.2017.03.003

493. Yehya, A. et al. (2018) Angiogenesis: Managing the Culprits behind Tumorigenesis and Metastasis. Medicina 54: 8. DOI: 10.3390/medicina54010008

494. You, W. \& Henneberg, M. (2017) Cancer incidence increasing globally: The role of relaxed natural selection. Evolutionary Applications 11:140-152. DOI: $10.1111 /$ eva.12523.

495. Yu J, et al. (2007) Induced pluripotent stem cell lines derived from human somatic cells. Science; 318: 1917-1920. DOI:10.1126/science.1151526

496. Yu S, et al. (2010) miRNA-96 suppresses KRAS and functions as a tumor suppressor gene in pancreatic cancer. Cancer Res 70: 6015-6025. DOI: 10.1158/0008-5472.CAN-09-4531.

497. Yu Z. et al. (2012) Cancer stem cells. Int J Biochem Cell Biol. 44: 21442151. DOI: 10.1016/j.biocel.2012.08.022

498. Yu, B. et al. (2017) Cytokine-induced killer cell therapy for modulating regulatory $\mathrm{T}$ cells in patients with non-small cell lung cancer. Experimental and Therapeutic Medicine 14: 831-840. DOI: 10.3892/etm.2017.4562.

499. Yuan S, et al. (2013) Effective elimination of cancer stem cells by a novel drug combination strategy. Stem Cells 31: 23-34. DOI: 10.1002/stem.1273.

500. Zeisberg M, Neilson EG. (2009) Biomarkers for epithelial-mesenchymal transitions. J Clin Invest 119: 1429-37 . DOI:10.1172/JCI36183 DOI:10.1172/JCI36183

501. Zeng, Z. et al. (2011) Nasopharyngeal carcinoma: Advances in genomics and molecular genetics. Science China Life Sciences 54: 966-975. DOI. org/10.1007/s11427-011-4223-5.

502. Zhang Q, Zhu B, Li Y. (2017) Resolution of Cancer-Promoting Inflammation: A New Approach for Anticancer Therapy. Frontiers in immunology 8: 71. DOI: 10.3389/fimmu.2017.00071.

503. Zhang, J., Medeiros, L. J. \& Young, K. H. (2018) Cancer Immunotherapy in Diffuse Large B-Cell Lymphoma. Frontiers in Oncology 8: 351. DOI: $10.3389 /$ fonc. 2018.00351.

504. Zhang, L. et al. (2015) Microenvironment-induced PTEN loss by exosomal microRNA primes brain metastasis outgrowth. Nature 527: 100-104. DOI. org/10.1038/nature15376. 
505. Zhang, W. et al. (2014) Lactotransferrin could be a novel independent molecular prognosticator of nasopharyngeal carcinoma. Tumor Biology 36: 675-683. DOI.org/10.1007/s13277-014-2650-1.

506. Zhang, Y. \& Weinberg, R. A. (2018) Epithelial-to-mesenchymal transition in cancer: complexity and opportunities. Frontiers of Medicine 12: 361373. DOI: 10.1007/s11684-018-0656-6.

507. Zhao M, et al. (2018) Upregulation of IL-11, an IL-6 family cytokine, promotes tumor progression and correlates with poor prognosis in nonsmall cell lung cancer. Cell Physiol Biochem.;45(6):2213-2224. DOI: $10.1159 / 000488166$.

508. Zhu, Y. X., Kortuem, K. M. \& Stewart, A. K. (2012) Molecular mechanism of action of immune-modulatory drugs thalidomide, lenalidomide and pomalidomide in multiple myeloma. Leukemia \& Lymphoma 54: 683-687. DOI: $10.3109 / 10428194.2012 .728597$.

509. Ziani, S. Chouaib, J. Thiery, (2018) Alteration of the antitumor immune response by cancer-associated fibroblasts. Front. Immunol 9: 414. DOI: 10.3389/fimmu.2018.00414.

510. Zucker S, Vacirca J.( 2004) Role of matrix metalloproteinases (MMPs) in colorectal cancer. Cancer Metastasis Rev.;23:101-117. DOI: 10.1023/A:1025867130437. 